
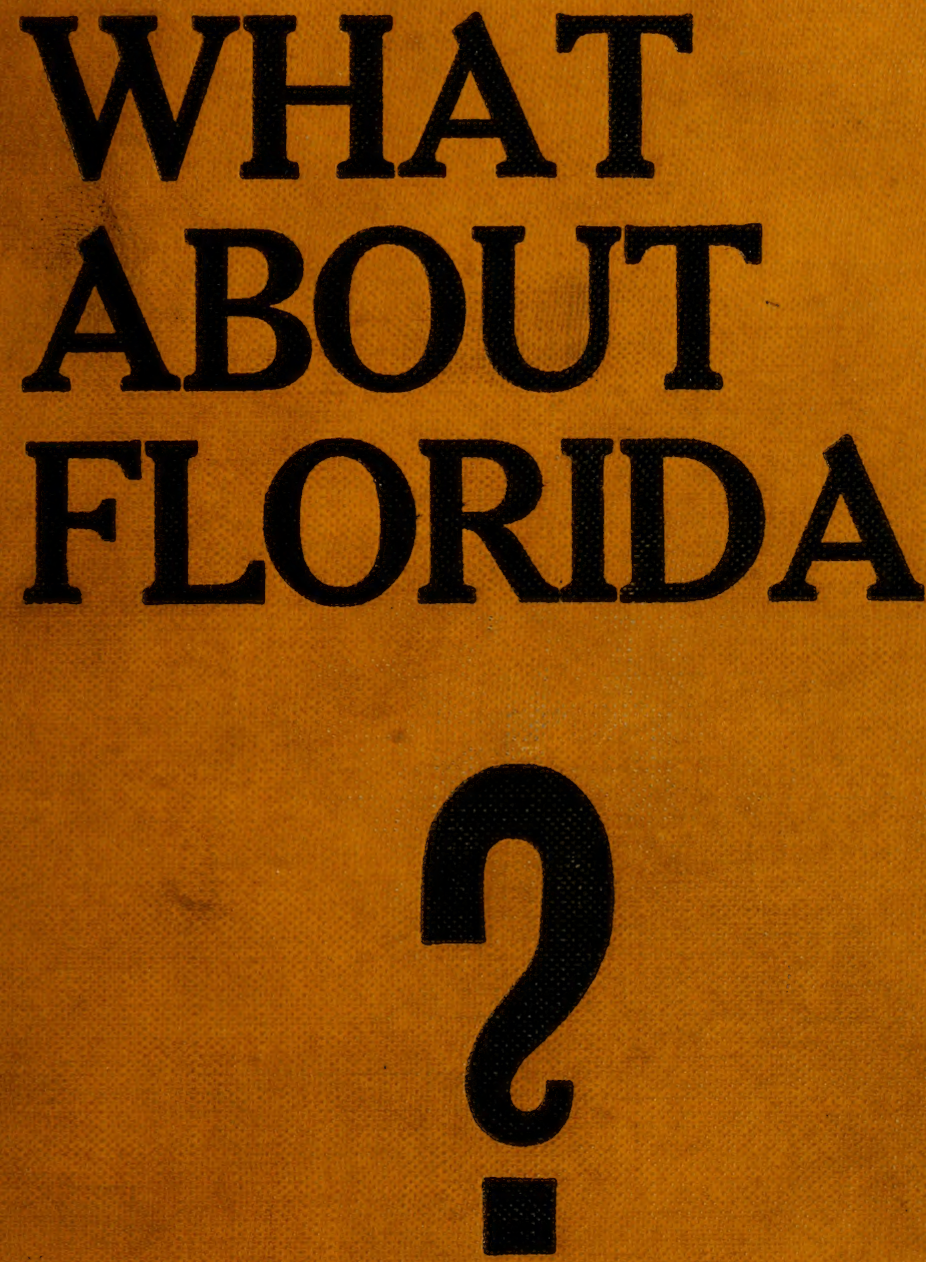

By

L. H. CAMMACK 


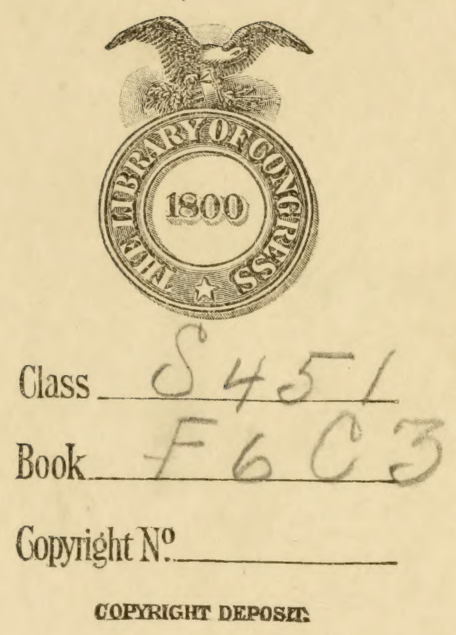





\section{WHAT ABOUT FLORIDA?}

BY

L. H. CAMMACK

if

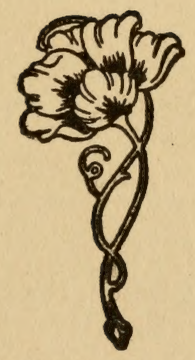

1916

LAIRD \& LEE, Inc.

CHICAGO 


$$
{ }_{56}^{5+51} \mathrm{C}
$$

COPYRIGHT 1916

By LAIRd \& LeE, INo.

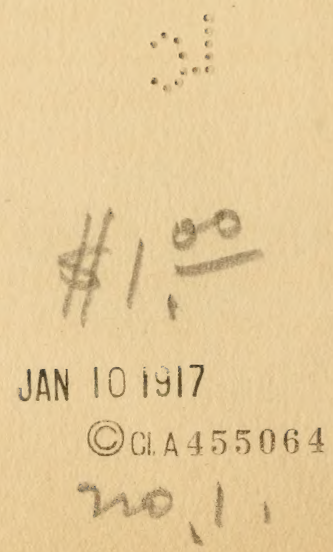




\section{PREFATORY.}

DiD you ever tour along an unknown country road, headed for a distant objective, run past the place where the roads forked, get five or ten miles down the pike and then find that you were on the wrong road? You berated yourself for overlooking the guide post or maligned the officials for failing to post the road, and wearily retraced the way. Guide posts are useful institutions, when used. They save a world of gasoline and profanity.

The next thing to no guide post, and much more reprehensible, is the post that points in the wrong direction.

For a long time there were no markers along the highway to Florida. Then individuals and organizations and promoting companies began erecting markers after their own styles, and these were frequently misleading. They caused many a traveler to make useless and costly detours, and had the road so littered with signs that the federal government had to take a hand in the interest of safe and sane travel.

Our purpose is to merely mark out the road to Florida; to indicate its superior points of vantage, and put bars across the road where there is a 
chance for the thoughtless to run into the ditch.

So many ludicrous stories have come back, and they have been so conflicting, that people would actually like to know whether it is a bonanza or a frost. We shall endeavor to answer the question in a plain and sensible manner, basing our conclusions on known facts. 


\section{CONTENTS}

CHAPTER

PAGE

I How Could Moses Decide?......... 7

II "Grapevine News" .............. 11

III Leading Questions-Often Asked..... 17

IV No Longer a Venture............. 23

V THE LAY of THE LAND. . . . . . . . . 29

VI Along the East Coast............ 34

VII The West Coast................ 43

VIII Dimensions, Distances and Data...... 56

IX What the Soll Is Good For........ 70

$\mathrm{X}$ That Fertullzer Question............ 81

XI What Can Be Raised Profitably?..... 88

XII The Story of the Orange.......... 100

XIII The Growers Got Wise........... 106

XIV Peaches Pay................. 108

XV Other "Best Sellers"........... 113

XVI Stock Raising................ 120

XVII The Everglades................ 126

XVIII TEN ACRES AND INDEPENDENCE. . . . . . . 133

XIX The Automobilist's Dream........... 142

XX The Booster Spirit............. 147

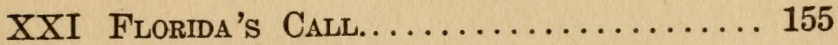

XXII “Iт's Uр то You".............. 169 



\section{CHAPTER I.}

\section{HOW COULD MOSES DECIDE?}

Put yourself in Moses' place.

Caleb and Joshua, two of his most reliable scouts, had pussy-footed all over the land of Canaan for six weeks, taking a straw vote on the number of the Amalekites and how big they were. There were eight other scouts along. Over in Eschol county they did a little foraging. Exhibit A was a bunch of grapes that took two men to lift, and they were as big as a string of bananas. They filled their pockets with pomegranates and figs. The whole crowd admitted on the witness stand that Burbank, in his palmiest days, never saw such fruit.

Caleb and Joshua voted to go right over and take the land-voted open ballot-on the table. They said it was Canaan for them. They liked grapes and had always wanted to live in a country where there was plenty of milk and honey. The milk flowed down the rivulets and the honey just naturally grew in the corners along the country road.

How could Moses decide?

The other eight were a lazy lot. They were afraid of work and did not intend to fight. Cold chills ran down their spinal columns every time 
they thought of those big husky fellows that lived up at Anak. They admitted that they liked grapes, all right, and would certainly enjoy staking off a little claim in the neighborhood of Naboth's fruit farm, but they understood that the old man was one of the fussy kind and carried a Colt's 38 under his cloak. It was just like making a date with the undertaker to go over there, and they did not propose to move.

What could Moses do? He knew that Caleb and Joshua were square, and that it was a cinch to put the thing over; but the eight stand-patters had scared the folks so badly with their stories that he could not get a rising vote to go over and swat the Philistines.

There they were, on the top of the hill, looking right down into a heavy laden vineyard, their mouths watering for grape juice, with a land grant from the highest authority, and yet they turned back north, hit a retreat, wired back home for transportation, lost their one good chance to succeed, and all because two sets of tourists down in Canaan could not agree on whether the country was ever going to amount to anything or not.

You know the story, of course. Certainly you remember. You cannot say whether it was in $\mathrm{Mr}$. McGuffey's reader or some other book, but a kindly looking, elderly lady called it to your attention years ago. Naturally one forgets many of these early teachings. 
It is a well authenticated story, all the same, and is as natural and human as if it had occurred only a year ago. People have not changed much in forty centuries. Some are naturally optimists and smilingly ask you to pass the cream. Others are by nature pessimists and suspiciously ask for the milk.

Caleb and Joshua have been touring Florida, off and on, for two decades. They have been proverbial boosters. The stories that they have brought back of oranges and garden truck would do credit to a Washington correspondent writing back to his home newspaper about the activity of his favorite congressman.

"Shiver my timbers," says Caleb, "if I did not see grape fruit trees down there that had four car loads of fruit on them, and there was not one fruit that was smaller than my head." Then Shaphat, who had trouble with every Pullman porter on the way down, comes back and says, "Yes, but you just naturally have to sit up with those grape fruit trees all spring, summer and fall to keep them alive. You have to pile fertilizer six feet deep around them, and then, nine chances out of ten, when you get a half-way crop, the price will be down and you have to feed them to the hogs."

But Joshua says, "I never saw such beautiful tropical vegetation in my born days. It was sunshiny all the time, although the folks wrote me from home that our water pipes had been frozen 
stiff for three weeks." "Yes," says grouchy old Ammiel, "but the mosquitoes nearly ate me alive, one night, and that rascally hotel proprietor wanted to charge me two bucks a day for a little room that would not have cost me over fifty cents in Terre Haute."

So it has gone for years. One traveler praises unstintedly. The other condemns unsparingly. Both cannot be right. Maybe both are wrong. Holy Writ assigns all men to places in the Ananias $C l u b$, but some of them get in by accident and some break in.

What is the real, actual Florida? It will be our aim to state the case as fairly as possible, from the common-sense, every-day standpoint. It will not be a compendium of statistics, but, rather, a birdseye view of Florida obtained from numerous trips and countless conversations with friends and foes in all walks of life. 


\section{CHAPTER II.}

\section{"GRAPEVINE NEWS."}

Of course you have had this experience many times.

You sit down in the hotel office, or the Pullman car, or the park, and compose yourself for a quiet spell of mental relaxation.

The unctuous looking stranger across the way glances amiably at you, coughs once or twice, then remarks on what a fine spell of weather we are having, and with little further prelude plunges into a spirited conversation on his pet theme. He begins by asking you if you have been to Florida, or intend going soon. As a necessary corollary he wants to know what you think of it. No; that is wrong. He does not care a rap what you think of it. His burning desire is to tell you what he thinks of it. Then he plunges forward as long as you show an interest or ask a question. He dilates at length, illustrates profusely, and convinces himself firmly once more that he is right and that few persons have had the keen perception he has shown in digesting the case.

Such opinions are just as interesting and usually as well founded as opinions regarding the foreign 
policy of our last administration. They depend solely on the view point of the expounder. If he is favorable, chances are he will laud to the skies. If he was a doubter before he made the journey, probably every circumstance will but commend his judgment as previously formed.

This relates to those who have actually set their feet in the sands, but the most pronounced views, the most oracular statements, pro and con, come from those who have never seen the St. Johns, or pulled oranges from a tree when the owner was not looking.

We all get notions. We form quick opinions. We like to tell a good story. Our imaginations help wonderfully.

Little wonder that Florida has been discussed in the past few years. A million people from the North have passed through Jacksonville, going and coming, in the past decade. A half million have considered Florida investments. A hundred thousand have bought without seeing. Many thousands have bought and moved to their possessions. Small wonder, then, that Florida has been the topic of discussion.

There are those who, with a charming freedom born of a desire to make things sound interesting, and based on an odd bit of information gathered here and there, will assure you that Florida is an almost unbroken desert, with here and there a little oasis. They aver that it is a howling wilder- 
ness, an impenetrable swamp; that the snakes and alligators hold high carnival around the few humble homes that are builded on the sand heaps. And they are firm in the belief that the white sand which covers this southern peninsula as a mantle is devoid of fertility.

On the other hand, people on pleasure bent burst from the confines of a stuffy office up north, take a short excursion, penetrate some of the better known resort districts of Florida, pull a few oranges, gather some flowers, listen to the birds, catch some fish, while away the hours in the balmy sunshine, and come back filled to the brim with roseate and highly colored visions of a miracle land, which make descriptions of Paradise look pale and faint and uninteresting.

\section{THE PROMOTER'S PARADISE.}

More insidious and more misleading than either of these is the shrewd promoter. He flourishes most generally in some metropolis of the north. Sometimes he has a brief residence in Florida, but this is only incidental, and not at all necessary to the part he is to play in his chosen enterprise.

The promoter purchases, for a song, some large boundary of land, which may or may not be attractive to the eye or useful to the husbandman. He does not begin the cultivation and development of the land. No, he begins at the other end. $\mathrm{He}$ engages the most adept handlers of English, and 
stipulates that they must bring out all the picturesque, alluring, teasing, convincing and inviting adjectives in their repertoire, and these he masses in solid, glittering phalanx, in a gorgeous description of his property. A brief inspection of these masterful word paintings will quickly convince the gentle reader that a new Arcadia has been discovered, that the beauties of the Orient, the wealth of the Indies, and all the good that humanity could desire, together with a life of indolence, ease and pleasure, is to be had by investing only a small sum in this southern paradise.

He does not permit these delectable visions to be marred by commonplace printing or insufficient illustration. He employs the finest photographers and sends them on voyages of discovery. Wherever they can snatch a charming vision of heavy laden groves, no matter whose the groves may be, or a bit of seashore, or a cozy little lake or a woodland scene, or anything of beauty, they are instructed to snatch it and adapt it to their own needs.

Then he employs the finest printers, the best color artists and the most expert engravers. Following this, with wild abandon, he piles up statistics showing the abundance of the crops, the ease of production, and the stupendous dividends that can be made per acre, with only the slightest effort, and all these he couches in a charmingly written, beautifully illustrated booklet. This finds its way, 
naturally and easily into the homes of those who are restless, who weary of the things they are used to, who are enamored with the distant and unknown, who have impatiently born the long and rigorous winters, who have longed for perpetual summer, and who, finally, have found an answer to a long cherished dream.

A CRUEL CHAPERON.

Literature of this class, beautifully gotten up, but entirely misleading, has in the past been sent out by the car load, and has found ready readers. It has given a wholly erroneous view of the real and actual Florida to multitudes of people, and has extracted mints of money from those who read.

This sort of public pillage has had a rude shock in the last few years. The Federal government had a large number of cases brought to its attention, and a series of investigations were begun, leading, finally, to the arrest of a number of very smooth four-flushers who had fleeced citizens of the North in a most reckless manner.

Some of these men now reside in Fort Leavenworth, some in Atlanta, and others are apportioned to various institutions owned by the government, where they have time to ponder over the error of their ways.

The government has gone further than this. It has been so paternal in its interest in the welfare of the common people, and so anxious that they 
should not be misled by ingenious schemers, that it has undertaken the censorship of all printed matter relating to land in Florida, and the gifted word painter who would now induce his fellow citizen to invest in a sure thing is most careful to see that the statements he makes, the pictures he draws, and the statistics he offers in evidence absolutely line up with the truth as it exists. You can rely on present day Florida literature.

This ruthless act on the part of the Federal government has had a depressing influence upon some of the most beautiful and poetic descriptive language that this generation has seen. It has put some ambitious schemers out of commission.

It has taken from the field of long distance real estate operations the blue print promoter and the smooth tongued persuader, but it has had the desirable effect of clearing up the atmosphere and of putting the sale of Florida lands and groves on a strictly business basis. 


\section{CHAPTER III.}

LEADING QUESTIONS-OFTEN ASKED.

WнAт about Florida, after all? Is it an arid desert-a wilderness-an unending swamp, filled with loathsome reptiles? Is it a land of quagmires, of pestilence, of disease breeding vapors? Does it abound in mosquitoes and insects, or is it a sunny paradise, where the great orb of day shines in undimmed splendor throughout the twelve months of the year, bringing fruit and vine and flower to early maturity; where the song of the bird is sweet and joyous, its plumage daringly brilliant, and where man may establish his palace or build his shack by the side of serene waters and may live his allotted years in peace and plenty?

Is its soil so eternally an unbroken sheen of white, gleaming, brassy sand, so sterile that you can "hardly raise an umbrella on it," as some have scathingly said, or does this sand mantle, under the fructifying influence of the husbandman's care, the spontaneous warmth of the genial sun, and the torrential rain, bring forth fruit and vine and flower, the massive pine, the gnarled cypress, the wide reaching oak in prodigal growth?

Is this great southern empire, that has commanded such searching attention for two decades 
from the people of a continent, simply the plaything of the promoter, the schemer, the organizer, the publicist, the designer, or is it, in reality, the lifetime opportunity for the man in the crowded north and east and west, to go to a new country, to buy productive soil, to raise paying crops, to market them to advantage, to establish his home, to rear his children, to carve out his fortune, and to become independent and prosperous?

Will the waste lands, the swamps, the cypress ponds, the low grounds be drained and dried and cultivated and rendered habitable, or will they remain throughout the years a menace to those who invade their boundaries?

Does it take a ton of fertilizer to produce a ton of cane or cabbage or tomatoes or, can a man raise these things in Florida at about the same cost that attends their cultivation in Ohio or Virginia or Minnesota?

Which set of witnesses shall we believe on the health question? Is Florida a land of mosquitoes, of sand flies, of malaria, and fever-is the air filled with noisome pestilence and heavy laden with the noxious odors of decaying vegetation, or is it a charmingly delightful, health giving region of bright sunshine, pure water, invigorating breezes?

Is it so sizzling hot and stifling and enervating and humid throughout the long drawn out summer months that life is unbearable and are the 
winter months so interspersed with frost and freeze that vegetation is endangered and crops ruined, or, shall we listen to the other seemingly credible witnesses who tell us, and prove by government statistics, that the mean average summer temperature in Palm Beach is no higher than it is in New York City, that a case of sunstroke was never heard of in Florida, that cooling breezes waft across the peninsula from ocean to gulf and gulf to ocean, rendering the nights comfortable and tempering the heat of the midday sun, and that so far as cold is concerned, a freeze has not been known in thirty years and the few slight frosts that come in the wake of blizzards that have swept the northern states have no appreciable effect on growing crops, and actually help the oranges and grapefruit.

Is the growth of the cities and towns ephemeral, transitory, spasmodic, temporary, or do we find the same strong municipalities, permanent industries, modern city improvements, well constructed buildings, churches, schools, colleges, theatres, parks, and the same class of citizenship that we have in the oldest and most settled of the states?

Is Florida a venture or a certainty? Is it purely a winter tourist proposition, where the grasping landlord may bleed the unsuspecting visitor, while cajoling him with the idea that he is warm and comfortable and having a jolly time? Is it sentimental, or practical? 
DE LEON HAD HEARD STORIES.

\section{It happened in 1533.}

The stories of Columbus' conquest had thrilled the world for a time and Columbus lay dead in an unmarked grave.

The possessions of Spain, under Ferdinand and Isabella had extended until the sun never set on Spanish dominions. When they rested in the marvelously beautiful Alhambra, they passed to King Charles, son of their only daughter, power and riches and territorial acquisitions that were the envy of the world.

Juan Ponce, Knight of Leon, was a great favorite of the young King Charles. He was the Von Moltke who had successfully prosecuted the wars of the nation. He had won for the crown and the people triumphs in arms and treasures and landed possessions. He was rich beyond the reach of avarice.

But he was old, and the king had just given him a young and beautiful wife. She was a dream, a vision, but he was old and decrepit, wrinkled and gray. He walked haltingly, heard with difficulty, and tottered about with faltering steps.

Ponce De Leon had been with Columbus on his second trip of discovery. He had seen the unknown shores and had heard with beating heart of the wonders the land possessed. He had heard of miraculous springs and that there was one 
great spring in some distant part of this unknown land, which, if one were to bathe, he would fling off the wrinkles and stiffness of age and from which he would come forth young and fresh and buoyant. The story allured him, held him, fascinated him, thrilled him. He had read of the impotent, the lame and the halt, who had dipped in that wondrous pool of Bethesda in old Jerusalem and had come forth whole. He decided to seek to the uttermost parts of the world for this fountain which could bring back the years that had been spent.

King Charles readily granted him a charter to go in and possess any part of the new continent that his heart desired, for King Charles was a liberal monarch. A few million square miles more or less made no difference to him. We fight now over a line fence that is three feet over the mark more quickly than Charles would have fought over the entire southern half of the United States.

De Leon organized his expedition, he spent a fortune in fitting it out. They traversed the seas for a year, finally sighting the shores of the continent they sought. They approached carefully, for there were men of an unknown tribe in sight. They landed at St. Augustine, planted the banner of Charles in the sand and took the country in the name of their monarch. Then they began search for the miraculous fountain of youth. Borne on the shoulders of his faithful band of intruders De 
Leon penetrated the wilds of Florida. It was De Leon and his Spaniard followers who gave the state its name. It was Easter Day when they landed. All the region was ablaze with the glory of early spring. Flowers were everywhere. So they named the new country Florida, meaning in Spanish, "the land of flowers."

The Spaniards looked long and earnestly for the great spring. The Indians grew suspicious. They misdirected them, and finally one of them got behind a convenient tree and shot an arrow at De Leon. He was so badly injured that medical help was necessary and none was to be had nearer than Cuba.

Juan Ponce, Knight of Leon, died. The Spaniards declared the new found country their own by right of discovery. They built their fort and named their city St. Augustine, and the ancient fort and morass stand today much as they left it.

Florida was found and named and first occupied by adventurers. They were looking for gold and not for a place to raise vegetables. The fountain they sought was there, and is there still. It does not restore. It preserves. 


\section{CHAPTER IV.}

NO LONGER A VENTURE.

Florida has passed the realm of the speculative. It is no longer a venture.

You do not doubt the stability of Ohio, though it has not been many years since California passed through the same inquisition that is now on concerning Florida. Still, there was a time when Ohio was only a part of the great Uncharted Northwest Territory. The man from Massachusetts who gathered his worldly possessions about him, placed his little family in a prairie schooner and started out bravely, only a little over a hundred years ago, to penetrate the wilds of Ohio, had greater forebodings and bade adieu to his friends with more pronounced tremor in his voice than does the hardy homeseeker now who starts to the regions beyond Nome.

Ohio was a venture. California was a venture. Kansas was a venture. Texas was a venture. They all made good. They made good because they had within themselves all the natural resources to make and keep life, and all they needed was the magic touch of human intellect and toil to turn them into the dwelling places of a strong and self reliant people. 
The lure of gold first brought attention to the Golden Gate. The lure of the gold in the orange has not been so bright but it has attracted the eye of many who now make their home below the 27 th parallel.

While the great West was being peopled with the hardier multitudes, and the pathways of civilization were being worn from the Atlantic beyond the Rockies, Florida had scant attention, because transportation was limited and uncertain and Chambers of Commerce and Boosters had not been discovered.

During this period life was so easy, and the means of subsistence so ready at hand that the families who had migrated and formed colonies in the more inviting spots were not nerved to ambition and energy. There grew up a languid, easy going, self satisfied, God-fearing, normal population, which planted groves, and engaged in the limited and easily satisfied culture of the soil.

Florida of today has passed any suggestion of self satisfied, monotonous cultivation of a few indigenous products.

Thoúsands of ambitious, sturdy, industrious, educated farmers, business men, mechanics, professional men and laborers have, in the past quarter of a century, been lured to the extreme South by stories of perennial sunshine, a delightful climate, and the chances for forging ahead in a new country. These are now the old settlers. They 
are an integral part of the state as a whole. They have adopted it in every particular. They have widened and broadened the scope of agriculture, have experimented and studied the soil, have sought new markets, have produced best sellers. They have joined hands with the original settlers and together they have brought forth an output that commands the attention of metropolitan markets, and this at a time when the northern producer is shut off from productive work by snow and sleet and ice.

If the Florida of today has passed the point of adventure and speculation into the region of certainty and known results in fruit growing, gardening and general farming, so that the statistician can tell you how many hundreds of car-loads of oranges and grapefruit, watermelons and strawberries and potatoes are sent to the central markets together with price paid for these commodities, and if the bank clearings and deposits in the cities of Florida show that great sums of cold cash come back to Florida in exchange for her product, then we might easily come to the conclusion that Florida production is a known factor from the standpoint of the farmer.

But Florida has another asset that is prospectively so great as to be beyond reasonable computation. There is scarcely a man in forty thickly settled states North, who, when he has gotten his stake, and comes to the time when he feels like 
sitting back and resting, does not dream of a little grove and a green lawn, a vine-covered cottage, and a motorboat in some quasi fairy land, where he may spend his declining years in comfort, and he inevitably turns either to Florida or California. The magic city of Los Angeles has been peopled in a few years largely by this class, who, having gotten ahead of the game, feel that they are justified in living where the weather is always temperate. It is from this same class that the great interest in Florida's growth has in recent years come. They translate the dream of years into a trip to Florida. They find the nook they are looking for. It may be along the Indian River, on the East coast, possibly as far South as Miami, or they may go into the lake region of Polk or Orange, or Lake County or they may find a grove or a pleasing situation on the gulf, but at any rate they come to stay. To men of this character, a life of indolence and uselessness is not attractive. They are not willing to sit supinely down and fold their hands, devoid of any serious care. They prefer a little orange grove or garden, or sometimes busy themselves with general farming. At any rate while the hands are busy the heart is happy, and they take up life with new zest and fervor, and it is easily demonstrable that the span of life for such as make their homes under such surroundings and amid such ideal conditions, is lengthened many years. 
Then from the standpoint of the tourist, Florida is indeed the land of opportunity. In the course of the year every man has a vacation, or at any rate, he is entitled to one. Some go to the mountains or to the sea shore during the heated months, but there is an astonishingly large and constantly increasing multitude who take a few weeks off during the extreme cold weather and fly to Florida. It used to be the pastime of the very rich and the millionaire class alone were able to patronize the palatial winter resorts, but moderate railroad fare and moderate priced hotels have lured great multitudes of people in ordinary circumstances to while away a few weeks in any one of a hundred places in Florida, and they find that this sort of a vacation is no more costly than the average beach trip of the Summer.

The tourist business, that is, the entertaining of tourists at hotels and boarding houses and the money that they scatter is one of the most important sources of income to Florida, and the sum total of these expenditures every season will run up into the millions.

One illustration alone will answer. St. Petersburg is a hustling, rapidly building little city on the West coast, twenty miles across the bay from Tampa. This little city is accredited with a summer population of about 10,000. Its winter population from October to May will frequently run 30,000 . It has more than one hundred excellent 
hotels, and an army of good boarding and rooming houses. It may readily be seen that if one little city entertains twenty thousand guests for weeks and months at a time in a single season, that this one source of income throughout the State of Florida is too important to be overlooked. 


\section{CHAPTER V.}

THE LAY OF THE LAND.

If 500,000 of our fellow citizens, through the influence of some great advertising campaign, were to decide to migrate to Panama or Brazil, and if varying reports of these countries would come back, some violently favoring them, some insistently disapproving, we take it that a friendly viewpoint, giving the general characteristics, would be worth while.

It would not be particularly illuminating to the prospective tourist, the visitor, or the investor, to know that on a given acre in a certain province in Brazil a man had been able to raise a thousand dollars' worth of cabbage in a season, or that on another acre in another province five hundred dollars' worth of hemp had been produced. It would be more satisfactory to turn one's glasses on the country as a whole, to know the general lines, the topography, and where the high points of cultivation had been reached. The geography of any country is the first thing you want to know about it.

One is always reminded of the old common school reader story of the five blind men who first went to see the elephant, and how each gave his 
opinion of the animal from the part he struck. The first bolted up against the broad side of the monster and declared that the elephant was very like a stone wall. The second got hold of the trunk and declared the elephant was very like a tree. The third grabbed the tail and decided the beast was very like a rope, and so on. Each formed his opinion from a certain angle, and while each was right, all were wrong.

Owing to its location and the way the railroads run, Jacksonville is the big front gate of Florida. Of course you can get into the state other ways, but from the standpoint of practical travel, you enter the state at Jacksonville. The roads entering this busy city have modern equipment and make good time from a number of the leading centers of the North.

We will take a glance at the state.

You pull into the terminal station at Jacksonville about 8 o'clock in the morning. Multitudes are leaving the various trains at the same time. Outside there is an army of 'busses and automobiles lined up. Most of the former are manned by the obsequious "cullud" driver, relic of the ante bellum days, who, with a great show of courtesy and submission to your wishes, invites you to enter his cab and be taken to any part of the city.

If you have had the idea that you are going into a proverbially sleepy and sluggish little Southern 
city where the colonels lounge around in luxurious ease, forget it. Jacksonville is a busy, bustling, energetic, thriving, thoroughly modern city with wide streets, impressive buildings, fine hotels, thorough street car equipment, cluster light system, and has an air of business that stamps it with the spirit of progressiveness. It has immense docks from which the largest vessels clear for points along the Atlantic Coast for South America and many European countries. When you register at the Seminole or the Mason, or the Windsor, or the Burbridge, or twenty-five other elegantly appointed hostelries, the service is modern and exacting as the most famous hotels of New York, Chicago, or Washington.

Thousands of well dressed, prosperous looking strangers throng the streets of the city at nearly all seasons of the year. This is their first stopping place on the trip further South, and many make this the end of their journey, attracted by the cosmopolitan life, the pleasing sights and the busy surroundings at Jacksonville.

There are about 75,000 people. The streets are lined, in the residence districts with artistic homes, and everywhere there is the tropic verdure, gorgeous flowers, majestic palms, graceful magnolias, and the most pleasing forms of floral ornamentation. The parks are beautifully kept. The sixteen banks in Jacksonville show resources of twenty-two million dollars, a mark that is not 
reached by many cities of the country with three times the population.

Jacksonville is on majestic St. John's River, seventeen miles from the Atlantic Coast with a thirty-foot channel admitting entrance to the largest vessels. Innumerable water craft come from all directions, laden with the products of grove and garden and mill and still, and fishing smacks are everywhere to be seen. It is a great distributing point for freight, and vessels of a dozen nationalities are always in port.

It is a city of fine clubs and delightful social activities. Its people are well-to-do, and they enjoy life. Automobiles throng every thoroughfare, and long runs down the coast and down the river are the daily pleasures of myriads of autoists.

There is nothing in the civic life of Jacksonville, in its buildings, or its people to indicate a temporary, mushroom growth. Everything has a look of solidity. Its future, as a metropolis of the South, is certain and even its competitors grant that at its present rate of growth it will at no distant day rival New Orleans.

When you leave Jacksonville for a trip through the state, you have two alternatives-the East Coast or the West Coast. These are general terms only, for the West Coast is a big term if you take it all in, but West Coast is the term generally applied to all the lower peninsula, except the land along the Atlantic Ocean. 
Thirty years ago two monied pioneers started developments in Florida. H. B. Plant on the West Coast and Henry Flagler on the East Coast. There was a great deal of rivalry between these multimillionaries, sometimes friendly and sometimes bitter. They were both builders and both enthusiasts. Flagler outlived Plant many years, and accomplished a more spectacular feat in the completion of his overseas railroad; but Plant laid the foundation for the later prosperity of the Gulf Coast, built mammoth hotels, like the Tampa Bay and the Bellevue, projected railroads, planted cities, and carved paths through unbroken wildernesses, blazing the way for a civilization that is wonderful. Flagler reared imperishable monuments, such as the church that bears his name at St. Augustine, and some of the great East Coast resort hotels, but his crowning achievement was the remarkable engineering feat of the railroad over the Keys to Key West.

Both names are held in veneration by the people of the state, and both were so intensely practical and common sense that generations hence will acknowledge the value of their pioneer work. 


\section{CHAPTER VI.}

\section{ALONG THE EAST COAST.}

Starting down the East Coast in a superbly appointed Florida East Coast train of yellow coaches and Pullmans, just as elegant as the effete East can boast, you have hardly crossed the majestic St. John's River before you run into the flat, marshy-looking country that persists throughout the two hundred miles. In less than an hour you reach the Indian River, a wide body of water, separated for a hundred miles from the ocean by a line of narrow keys.

St. Augustine is the first real stop of importance. This ancient land-mark, the oldest in the United States, is a gem of antiquity. The streets are narrow and crooked, the buildings are hoary with age, and fossils and relics abound on every hand. The ancient fort and morass are still preserved in much the same condition in which they were abandoned by the Spaniard.

But St. Augustine is a curious mixture of ancient relics and modern perfection. The Alcazar and the Ponce de Leon are two of the most costly and delightfully appointed hotels in the country and they are thronged in season with the wealth and beauty and culture of the nation. The city, 
itself is one great curio and in it are gathered shops and stores representing all nations. A street car ride takes the tourist across the Indian River with its myriad boats and launches, to the beach where usually throughout the winter months the water is thronged with bathers.

Everything in America is so new and has so much the impression of the "fresh paint" sign that the sightseer takes with avidity to the antique, the fossilized, the old-fashioned, so St. Augustine not only furnishes interest to the patriot who stands awe-struck before the marks of the earliest settlers in the Western Hemisphere, but it satisfies the curiosity of that class of our citizens who have for years been gathering a little coin together in the soap business or the mine and then trotting over to Europe to look at the relics.

St. Augustine revels in relics, but the reveling is tinged with commercialism. It vies with Jamestown and Plymouth as places of interest for the historian and the antiquarian.

There is no scarcity of people down the East Coast for the local train makes one hundred and sixty stops between Jacksonville and Key West.

The traveler is amazed at the imposing list of palatial hotels and attractive resorts that beckon him with tantalizing pictures of fairy land in a day's journey.

His first impression on leaving Jacksonville or St. Augustine is depressing. The train will bowl 
along, forty miles an hour, for a seemingly interminable spell, while the view on each side from the car window reveals only an unbroken stretch of flat, saw grass land, punctuated with pines and interspersed with patches of palmetto, and everywhere marshes and ponds and swamp. He will catch an occasional glimpse of a heron or some brilliantly plumaged tropical bird, and will be on the border of deciding that he has reached the uttermost limits of human habitation, when, suddenly, he emerges into a miniature paradise of gorgeous flowers, well ordered groves, artistically decorated lawns, inviting little bungalows, pretentious palaces, and will whirl by a velvety carpeted golf course, where gaily dressed men and women are intent on their sport, while in the background will loom up as if by miracle, one of the great white winter hotels.

Florida is cultivated in spots.

It is only natural that with an acreage of thirtyseven millions and a population of one million, these spots should be sparse. If Florida were as thickly settled as Pennsylvaina or New Jersey it would be so intensively and so extensively developed that the average man would lose all taste for heaven and take Florida in preference. Where it has artistic culture there is no place this side of primeval Eden or the sunken gardens of ancient Babylon that can rival it in beauty.

Where the magic touch of man's hand is not in 
evidence it is strange and weird and wonderful, and the superlative beauty of these chance spots that are redeemed from the wilderness only indicate what may and will, one day, be done over the entire peninsula.

But these great hotels which entice the rich and gay and frivolous, those overcome with ennui, those who are looking for change and adventure, those who are fleeing loneliness, are veritable dreams, reared, as they generally are with a natural background of rank native floral and tropic luxuriance, and facing, as they usually do, some quiet stream or the restless surges of old ocean. Their courts are tropical bowers, redolent with balmy perfume, suffusing the senses with a mystic feeling of luxury and ease. Sunshine and gladness, flower and fruit and dreamy stream and all the radiant splendors of the semi tropics greet the spectator at every point.

Passing prosaic Hastings, which is known only to fame as the southern home of the potato, the first of the famous resort towns is Ormond on the Halifax, with its pretentious and popular Hotel Ormond and its justly famous Ormond Beach, across the keys, the rendezvous for bathers, health hunters and pleasure seekers.

The town of Ormond is crisp and fresh and progressive and, like almost every municipality in the state, shows a sturdy and substantial growth.

A little further down is Sea Breeze, with its 
rugged natural scenery and its world famous automobile race course along the beach. This course extends for miles along the sandy beach, is firm, but slightly resistant, and is the delight of speed maniacs.

Daytona, a popular resort city, full of big hotels and all of them full of guests, is an all-the-year town, with an increasingly large population of well to do pecple, who have settled permanently in this beautiful spot and are building a thriving city along the most modern lines.

Daytona is on the famed Indian River, which is not a river at all, but an arm of the sea. For over a hundred miles the keys along the coast protect the inner waters from the ocean and form a quiet river-like stream which is so much like a river that it has earned the name given it. Boats ply this stream, going as far as Jacksonville on the North. It is the great gathering place for fishing craft, sail boats and speedy motor boats, and races are frequent.

Twenty miles further south is New Smyrna, a vigorous young city with many attractions for the tourist, not the least of which is the charming Coronado beach, just beyond the Indian River.

Titusville, forty miles below, is a rapidly developing commercial and agricultural center, with a wide stretch of the placid Indian River at its feet and direct rail connections with points on the West Coast. At Titusville large drainage and land 
recovery projects have been undertaken and wide areas of productive territory opened to cultivation.

Drainage projects have been numerous and important at many points along the East Coast, but at Sebastian, seventy miles south of Titusville, one of the most stupendous private reclamation plans has been under way for a number of years. The Felsmere Company, owning one hundred and eighteen thousand acres of flat, damp muck land, has invested nearly two million dollars in main and lateral drainage canals, has constructed a railroad, built a town, and has opened up for cultivation large boundaries of what is said to be unusually fertile and tillable muck land.

Towns along the way are numerous, but Fort Pierce, St. Lucie and West Palm Beach are among the most prosperous and rapidly growing. Each has sprung up in the course of a few years and all of them have an increasing quota of winter visitors.

At Palm Beach is located the Royal Poinciana, known as the largest hotel in the world, and universally recognized as the greatest and gayest of winter tourist resorts.

To this magnificent white palace come the elite of all lands, from January until March, for the social frivolities of the mid-winter season. This mammoth building, situated in the midst of a cocoanut grove, with graceful asphalt walks, bordered with gleaming poinciana and vari-colored 
flowers, with its lawns carpeted perennially with a rich and velvety covering of St. Lucia grass, is the recognized acme of luxury and elegance. Its majestic proportions, unequaled beauty, the character of its thousands of guests, its dazzling social functions and its ultra-exclusiveness have almost won the favorable comment of many of our wealthy and wandering Anglo-maniacs and continent trotters who admit that there is one place in America aristocratic enough for them to stop at.

But Miami is the tropical mecea to which thousands of frost-bitten tourists journey each year, and it is one of the most conspicuous examples of modern city building to be seen in the south, or for that matter, in the entire country. The Royal Palm, the Halcyon and other richly appointed hotels are the chief attractions for visitors and are the objects of civic pride, but the municipality itself, the public building's, the modern stores, the palatial homes, the thrift, the bank deposits, the surrounding fields and farms all mark this as one of the great coming centers of the extreme south.

From Miami a fleet of fine passenger steamers clear for Nassau and the Bahamas.

While Miami is a marvel of commercial activity and the number of spacious and imposing buildings erected within the last few years shows the stability of the city itself, yet Miami is backed by a truck territory that produces wonders. Back of the city is a rich muck that is well adapted to vege- 
tables. From this comes enormous crops of tomatoes and other vegetables, which are shipped to the great markets in solid trains and are a determining factor in the financial interests of the growing city.

The territory around this one city is but an example of what is taking place all over Florida. Time was, not so many years ago, when the hardy pioneer merely skirted the shores of the Atlantic from St. Augustine south, and rarely penetrated a mile from the shore, except on hunting expeditions or when in search of adventure, but, gradually the waters that enveloped these low lying plains throughout the ages, are being driven back into the ocean, the low lands are being conquered, the jungle is being cleared, and behold, from the tangled wilderness has been wrested a million acres of soil as rich and fertile and responsive as the far famed valley of the Nile.

From Miami and Fort Lauderdale are projected great drainage canals, capable of carrying on their bosoms great steamers, and these man-made water highways bear traffic to Lake Okechobee, from which navigation proceeds to Fort Myers and Kissimmee and other places on the West Coast. Railroads across the same territory are being projected and built, and, within a few years, the East Coast and the West Coast, the Atlantic and the Great Gulf, separated throughout unknown centuries by an impassable abyss of water and jungle 
and swamp grass, will be brought together, the intervening seas be drained and the soil be made of use to man.

Key West is the final port of entry and railroad terminal at the southernmost extremity of the North American Continent.

For decades it held supremacy as a cigar making center, and still is well known to smokers the country over, but the rise of the industry in other parts of Florida has drawn specific attention from Key West.

Since the completion of the Florida East Coast Railroad it has become a great shipping center and has intimate connection with the big volume of passenger and freight business transacted by the country with Cuba. It is but a night's ride from Havana.

Although eighty miles of water intervene between the shores of the two countries, the passenger can take his Pullman berth in Havana and stay in the same car until he reaches his destination in Washington or New York. 


\section{CHAPTER VII.}

\section{THE WEST COAST.}

THIs coast is served by two main lines of railroad, the Atlantic Coast Line, which penetrates almost every section in the state, and the Seaboard Air Line, which has numerous branches.

Again it is well to call attention to the fact that the term "West Coast" applies in a general way to whatever is not on the East Coast. The long distance from Jacksonville directly west to Pensacola would hardly be, strictly speaking, West Coast territory.

Let us digress far enough to prophesy that one day a great trunk line, originating in Chicago, or perhaps some other large Northwestern metropolis, will push its way through the Southern states and on down through Florida, irrespective of existing lines, bisecting the state.

After an hour's run along the banks of the picturesque St. John's River on the Atlantic Coast Line Railroad, we reach Palatka, a prosperous city of ten thousand, with four railroads and large shipping and lumber interests. The St. John's is one of the few great rivers of the world, like the Amazon and the Nile, to flow north, and while it is fresh water and has a sluggish current, it is in 
reality for the most of the distance from Jacksonville to Sanford, only a big lake, reaching its maximum width in the great inland sea thirty miles south of Palatka, known as Lake George, a body of water seven miles across and fifteen miles in length.

Near Palatka, a company has set out a hundred thousand camphor trees, basing their venture on the long held theory that these would flourish and be remunerative in this genial soil and climate. The trees are not yet past the experimental stage but are robust and healthy in appearance, and, grouped around this agricultural arena, with gaze intently fixed on the outcome of this experiment, are a host of scientists and agriculturists who impatiently await the outcome. If success crowns the effort, then a new vein of gold is found in Florida. In this section are also numerous large peach orchards which present a charming picture in March, when the whole landscape is covered with a glowing sheet of pink blossoms.

De Land, fifty miles to the south, is a delightful little city, with giant live oaks shading its well kept streets and with elegant homes on either side. De Land is the seat of Stetson University, one of the foremost colleges of the South and named for its great benefactor, John B. Stetson.

Just below is the thriving city of Sanford, which you enter through broad vegetable gardens.

Sanford has become known as the center of a great celery and lettuce raising district, and the 
grower holds full sway. One feature that has contributed to the success of this territory is that Artesian wells-the waters strongly impregnated with sulphur-abound and a quick and permanent flow is easily secured.

Four divisions of the Coast Line radiate from Sanford, giving it precedence as a railroad point, and this, also, is the head of regular steamboat travel on the St. John's.

A few miles west of Sanford begins the great lake country of Florida in the Highlands, sometimes spoken of as the backbone of the State, one of the most delightful and healthful sections of the South. Most of the State is a uniform, level stretch, not many feet above sea level and much of it in need of drainage, but this region is not only three hundred feet above sea level, but it abounds in myriads of fresh water lakes, large and small, these having white sandy booms and beeches and the water being pure and drinkable.

The prevalence of large lakes and their tempering effect on the atmosphere when there are sudden changes, have also given this section precedence over the low country, because the occasional frost which nips the tenderer fruits and vegetables in other localities, loses its bite in this higher altitude and this fact is of commercial importance to growers.

Throngs of winter visitors, especially those who love fishing, boating and bathing, select this region 
and they find ample accommodations at Tarares, Eustis, Clermont, Mt. Dora, and other near-by towns. At Clermont a great deevlopment has taken place under the charge of the Lake Highlands company, a club house, experiment farms, and quite a little city of bungalows has been built overlooking Lake Minnehaha.

Just below Sanford is Orlando, the Beautiful. Orlando is far ahead of even the average aggressive Florida city. Nature began the work by planting numerous little sparkling lakes right where the city was to be and man has taken advantage of these natural conditions and added ever-pleasing touch. Princely trees adorn the streets and parks, and surround the lakes. Swans float lazily in the limpid waters and the weird and fantastic Spanish moss festoons the trees.

Kissimmee, twenty miles south, is a growing city, a clearing place for large lumber interests, and the point from which boats ply the Kissimmee River to that great Inland Sea, Lake Okechobee, 200 miles distant.

Lakeland, just below, is one of the commercially promising cities of the Highland country. It is a husky town, full of ginger and pep, and the "get there" spirit, and an important terminal point for the Coast line. It is honey-combed with lakes, and these lakes are fast becoming centers of ornamentation and development.

From Lakeland, it is but 125 miles to Fort 
Myers, one of the Southernmost points reached by railroad on the Gulf Coast. Fort Myers, on the Caloosahatchie River, profits by an ideal location and many attractions for winter visitors, not the least noted of whom is Thomas A. Edison, who makes his permanent winter home at this place, in a villa surrounded by royal palms.

Tampa is an aggressively active city, and has had a spectacular growth, the beginning of which may be dated to the Spanish-American war. Before that time it was simply a haphazard collection of common-place houses, thrown together at random, without aim or ideal. With public attention focused on Tampa, and with growing shipping interests, Tampa began to round into form soon after the Spanish-American war, and has made great strides ever since. It has seventy thousand people, including its environs at Ybor City and West Tampa. A large number of these are Cubans and Spaniards, attracted hither by the allimportant cigar business, for Tampa holds the world's record in the manufacture of high-grade cigars, averaging almost a million cigars a day, all of them hand-made, all of them from selected tobaccos, and the price of many running as high as fifty cents and one dollar each.

To the traveler and the sightseer it is known for the celebrated Tampa Bay Hotel, a magnificent Moorish palace, erected and lavishly furnished by Plant at a cost of $\$ 3,000,000$ and later sold to the 
city for a nominal sum. This unique and massive structure with its artistic setting of palms and tropical plants, and its picturesque location, overlooking the river and the Bay, forms one of the most charming pictures in all the Southland.

But Tampa has all the self-relying qualities, the vim, the energy, the foresight, the spunk, to make a great city. For instance, a million dollars are now being spent for hard roads, a municipal hall has been erected at a cost of two hundred and seventy-five thousand dollars. Harbor improvements have run into the millions, and the estuary project is one of the most stupendous on any coast. Tampa not only entertains a large number of the winter visitors, but its activities are perennial. Exports are heavy, owing to the tremendous tonnage of phosphates, lumber, resin and other natural products shipped from the nearby counties. It is known as a $\$ 38,000,000$ port.

A twenty-mile boat ride down the bay brings the visitor to that magic city, St. Petersburg, one of the popular gathering places on the West Coast for winter tourists. Along the docks, long rows of anglers can always be seen, trying to beguile the fish, while, hovering about, as tame as barnyard fowls, are hundreds of somber looking pelicans, and, soaring above, myriads of sea gulls.

The sun always shines here, or at least it is so regular that one of the live wire local dailies has had a standing offer for years, to give, free, its en- 
tire edition every day the sun fails to beam on the city. Last year the publisher gave away his paper eleven times.

With Tampa as a center, a circle drawn forty miles takes in a number of important and fastdeveloping points, and this imaginary circle will include a region which, on account of its natural scenic beauty, its coast line, its bays, bayous, keys, beeches, its mild and healthful climate, its productivity and varied resources, will one day soon be one of the most populous, popular and wealthy sections of the United States.

Within this circle, only a few miles North, are the greatest phosphate beds of the world.

Within this circle are little keys and islands on which rich men will establish their castles, and in regal splendor reign over their miniature principalities.

Within this circle is the rich Manatee country, a vast domain weighted down with groves and gardens, and down the coast thriving municipalities such as Bradentown, Manatee, Palmetto and Sarasota, compact, well ordered, booming little cities, while great plantations and estates are being brought under cultivation, and such nationally known names as the Palmers, the Ringlings, and others, stand out in bold relief.

In the same circle is Clearwater with its spectacular developments of a decade, and its impressive Bellevue Hotel, and Tarpon Springs with its 
picturesque bayous, its palatial homes, and its unique flotilla of Greek vessels engaged in the sponge industry.

It is only a prophecy, but a well founded one, that Tampa with its strategic location, its estuary, its thirty-foot channel to the sea, its increasing volume of imports and exports, its background of phosphates and timber, and the new field opened by the Panama Canal, and the South American trade made possible by the world war, will grow so rapidly in importance as a port of entry and a terminal that it will out-distance all competitors on Southern coasts.

The Seaboard Air Line Railroad, the most direct line from Tampa to Jacksonville, has played a conspicuous part in opening up Central Florida, and along its line are many important towns.

Ocala, in Marion County is a well built and a wide-awake city of nearly ten thousand, surrounded by a prosperous agricultural region, and on the edge of a large phosphate belt.

Near Ocala is the renowned Silver Spring, one of nature's wonders, a mineral spring of extraordinary transparency, bubbling up out of the earth with a flow of 368,900 gallons a minute, and of such volume that large steamers coming up the Oklawaha River, to this, its fountain head, turn in the spring and start on their down river journey.

The spring is deep, so deep that no diver has 
essayed to explore its bottom, but so wondrously lucid that small coins or other bright objects show clearly a hundred or more feet below, and the refraction of the sun's rays, and the lens like effect of so deep an abyss, give to fish playing around in the unknown recesses of the pool, distorted, fantastic and magical shapes and colors.

For generations this striking natural phenomenon has exercised a strong influence over the imaginations of men and has been a source of interest and deep study to scientists.

There is good reason to believe that the fame of some such Spring as this, either the Silver Spring, or a similar one at Juliette, or the noted Sulphur Springs at Tampa, carried by the Indians, and by them transmitted in tempting story form to the Spaniards, first induced Ponce de Leon to explore the interior of Florida in search of the illusive Fountain of Youth.

One of the delightsome sensations in inter-Florida travel is the trip from Silver Springs down the winding and erratic Oklawaha to the St. Johns and thence to Palatka, a distance of 135 miles.

The boat plungres from the Spring into interminable thicket, beneath over-arching trees, dense in shade and hanging low with Spanish moss. The channel is deep enough for an ocean-going schooner, but so narrow and so abruptly winding that the steamer touches the bank on one side while the boughs of cypress and gum scrape against the 
cabin on the other. One seems lost in a wild African jungle at one minute, and in another emerges into an open country with broad fields and green meadows. It is a favorite pastime of the traveler to try to see an alligator. If he watches carefully ahead he may see once in a while one of these curious reptiles slide easily from his sunning place amid the dense foliage that carpets the low banks on either side of the river. At night torches are lighted, the glare giving to the scene one of indescribable weirdness, and when the darkies on the lower deck chant the low, tremulous melodies of their race, the combined effect is that of a strange, supernatural and impossible dream. Yet you wake up at Palatka the next morning after a short sleep and find the old world moving on in its usual hundrum way.

Gainesville on the Seaboard is a modernized, well improved, wide-awake little city, the home of a prosperous people, and more important because it is the seat of the State University, and entertains many hundreds of the State's ambitious "Rah Rah", boys and girls throughout nine months of the year.

Twenty miles to the Southwest is Williston, which might commonly be known as a water-tank station, were it not for "cukes." The cucumber has put Williston on the map. Carrying cucumbers to Williston would be the equivalent of carrying coals to New Castle. 
The world likes cucumbers, especially when they are high-priced, and it pays a fancy price for them in the early spring. The growers around Williston have a congenial soil and a favorable climate for raising cucumbers in quantities-hence it is that the demand in the Northern market finds supply in Levy County, and while the gales of March are sweeping over the barren fields of the North, the Williston trucker is imitating the busy little bee from early morn till dewy eve, and with jealous care, coaxing his coming crop.

In April and May the crating and shipping begin, and buyers throng the local depot platform. Fifty-seven thousand crates of "cukes" have left this one station in a single season. Small wonder, then, that King "Cuke" is held in great reverence.

This same table delicacy is grown successfully in a hundred other Florida sections, but certain points become known transcendently for one thing. Williston's fame rests with the cucumber, and Williston is content to let it go at that.

The Western Panhandle of Florida is, in dimensions, almost an empire by itself, it being nearly four hundred miles from Jacksonville to Pensacola.

Tallahassee, the quiet, dignified, easy-going old capital, is a hospitable and pleasing city to be in, and is not only the comfortable abode of those connected with the State government and the seat 
of two colleges, but attracts large numbers of visitors who are drawn by the complacent and restful air, and by the social and intellectual environment of the capital city.

Two important points lie West of the capitalAppalachicola and Pensacola. The former is a port of entry, has direct steamer connection with Mobile and New Orleans, and ships large quantities of oysters and lumber. Its maritime trade is of growing importance and is destined to make this one of the principal ports on the Gulf Coast.

Pensacola is a strategically located Gulf Port city at the extreme western end of the State, and fully nine hundred miles from Key West, the other extreme. It was settled by the Spaniards in $\mathbf{1 5 5 5}$ and is admired for its broad and densely shaded streets and handsome homes. The fishing industry is the most extensive on the entire gulf, and the lumber industry is enormous, employing thousands of men.

The Spanish conquerors who first subdued the Indians and established colonies have left their impress on the names of streets, and Spanish derivatives show color in the naming of streams and natural phenomena just as the Indian occupancy of Florida through past centuries has left its mark in the naming of rivers and bays and inlets and lakes. Where else in the world are there names more indicative of the noble red man than are to be found in the "Caloosahatchie" River, Lake 
"Tohopekaliga," Lake "Palatlakaha," the "Suanee" River, Lake "Okechobee," the "Kissimmee" River, Lake "Minnehaha," the "Oklawaha" River, and down on the Gulf Coast ten miles from Tarpon Springs, close to Anclote Harbor a little river exists with the charming name of the "Pithlachacootee." Still, this is more pleasing than one of the points near known on the map as Hog Island. 


\section{CHAPTER VIII.}

DIMENSIONS, DISTANCES AND DATA.

We purchased Florida, and a few other states thrown in for good measure, from Spain, in 1821, and two good crops of oranges from the laden groves would pay all that Spain received in the transaction.

Florida has approximately thirty-seven million acres of territory. Sounds very simple, but it is hard to appreciate. Its area would equal the combined areas of Maine, New Hampshire, Vermont, Massachusetts, Rhode Island and Connecticut, six of the most thickly settled of the New England States. The population of Florida is slightly in excess of one million, while the population of the six states mentioned is over fifteen million.

If these states in the North are able to support the enormous population that calls them home, and that in spite of the fact that much of New England 's "rock bound coast" is rugged and bare, what an army Florida would feed if her thirty-seven million acres were developed to the superlative degree that we find in the Eastern states.

According to the best estimates made by Federal and state engineers about eighteen million acres of 
Florida is covered with water, principally in the Everglades.

Florida is a state of magnificent distances. It has twelve hundred miles of sea coast. This is as much as all the rest of the Atlantic seaboard states together. It is also a fact that must be reckoned with if the question of national defense against a foreign foe should ever reach the acute stage.

Take a few distances, for example. From Fernandina on the north to Key West on the extreme south is 560 miles, or as far as from Columbus, Ohio, to Birmingham, Ala.

The distance east and west, from Fernandina to Pensacola is 410 miles, or as far as from Chicago to Knoxville, Tenn.

When the newly elected member of the legislature at Key West starts to the session of that body at the quaint old capital, Tallahassee, he has to travel eight hundred miles to get there. Part of this distance is occasioned by the elbow around which he has to bend, but, aside from Texas and California, there are no states in the union where one may travel so great a distance in practically a straight line, and still keep in the bailiwick of the same governor.

This vast domain, including so many parallels, has a varied soil, climate and fruitage. In the north an occasional whiff of snow is seen. Around Tallahassee and the western wing there is a red 
clay soil and a rolling country not unlike the blue grass section of Kentucky, and the same grains and fruits are produced. In the center of the state it is semi-tropical, and in the extreme south it is purely tropical, so one can run the whole gamut of climatic changes and still be in the one state.

One of the most remarkable engineering achievements of the age was the construction of Flagler's overseas railroad, the Florida East Coast, from Miami to Key West. It jumps from key to key for a distance of almost two hundred miles, and if Flagler had not run out of "keys" he would have run passengers into the terminal station at Havana. As it is we are but eighty miles from Morro Castle by rail and this country practically joins hands with the republic to the south and is almost bound by iron bands.

The railroad mileage of Florida increased from 3,361 miles in 1900 to 6,500 miles in 1915 .

Three hundred million dollars are invested in Florida hotels.

The estimated increase in population for the last five years has been 30 per cent, while the bank deposits have increased from $\$ 44,000,000$ to $\$ 90$,000,000 in the same period.

Florida is not looked on as a corn state and yet the Agricultural Department figures Florida's 1915 corn crop at $\$ 10,000,000$.

According to the last census report, and that was taken a number of years ago, there are 50,016 
farms in Florida, with a capital investment of $\$ 143,183,000$. Implements and animals and farm equipment were valued at $\$ 25,037,000$.

How would you estimate, in figures, the tourist business for a season? Last winter there were, conservatively, 200,000 persons from states north, who took a trip to Florida. Some stayed a week, some stayed four or five months. The average would be a month. The average expenditure would be $\$ 5.00$ a day. This would make $\$ 30,000,000$ at the very lowest calculation, rolling into the coffers of the state from visitors. It was probably twice this amount when railroad fares and purchases are included.

Perhaps you never thought of Florida as a mineral producer. But it is. When Providence spread sand all over the peninsula, it also planted beds of phosphate from which to make fertilizer that the sand might be made to produce. The phosphate industry is of no mean importance. There are three veins, each usually found in layers of from four to seven feet in depth, near the surfacethey are the Pebble Phosphate, the Hard Rock Pebble, and the River Pebble.

Phosphates are found in ten Florida counties, the largest deposits being in Polk County; \$125,000,000 are invested in the industry in land and equipment; 10,000 men are employed, and last year there were shipped 2,504,794 long tons of phosphate. Immense quantities were exported to 
Germany before the European war, and since 1914 it has been quiet, but necessity has forced domestic use on a larger scale and the war may have been a disguised blessing to Florida producers and users.

Two hundred eighty-seven million cigars were sent out to the smokers of the country from one Florida city last year.

There are 657 varieties of fish in Florida waters. The thousands of fresh water lakes in the interior abound in bass, perch, jack-salmon, cat fish and the myriad other commonly known varieties. The gulfs, inlets, bays and bayous literally teem with fish, from the game King fish and the elusive Tarpon to the non-combatant Mackerel.

If all the oyster beds of the country were put out of business at a single stroke, the waters around Appalachicola, Pensacola and a few other Florida fishing ports would supply the demands of the nation.

Florida is rightly named "the Land of the Lakes." It has uncounted thousands of fresh water lakes, from the clear little pond, no larger than a city square, to great inland seas, such as Lake Apopka in the north-thirty-two miles longand Lake Okechobee in the south, forty-five miles in length. Lake County, alone, near the center of the state, has twelve hundred of these pure, fresh water lakes within its borders. These are not sink holes or undrained basins which have been filled 
by heavy rains. They are majestic bodies of water, many of them, such as Lake Harris, Lake Griffin, Lake Dora, Lake Eustis, Lake Louise, Lake Minnehaha, Lake Minneola, none of which is less than two miles across. These are, in most instances, connected by picturesque, winding little rivers, and from the standpoint of practical navigation will all, probably, one day form parts of a great water chain connecting the interior of the state with the wide sweeping St. Johns River and then on to the ocean.

The water in these lakes is pure and healthy and drinkable. It is slightly tinged with tannic acid from the roots of the palmetto but the lakes are fed by living springs, have hard sandy bottoms and beaches and are favorite resorts for bathers.

The average annual death rate is only nine to the thousand. This is the lowest of any state in the union.

Florida has $75,000,000$ standing, merchantable trees. In spite of the far-reaching raids that have been made on the pine forests and the cypress groves, the bass, the oak and the hemlock during the last forty years, at a time when economy and conservation were not in the vocabulary of the timberman, Florida still has lumber for the building interests of the world for many a year. Added to the virgin growth are vast areas of carelessly cut-over lands which have an appreciable amount 
of standing timber that can be utilized to advantage at the mills.

Florida has not been paying $\$ 4.50, \$ 6.00$ and $\$ 7.50$ per ton for coal while there was a scarcity and prices were soaring. Florida has its supply of fuel for many generations in the pine trees that are standing around waiting to be used as fuel because too small to be cut into lumber, so the fuel problem will not in half a century be $a$ paramount issue in this state.

There are 175 varieties of timber found in the state, an exhibition of 140 of these having been given at one time.

Florida is essentially a dry state, only five counties having saloons and these only a limited number each.

Florida is the chief producer of Fuller's earth in the United States, 75 per cent of the national production having come from the one state. It is used chiefly in clarifying mineral oils.

Florida used to import its brick almost entirely from Georgia and Alabama, but last year the state made 41,901,000 common or sand lime bricks for local use.

The world looks to Florida for an appreciable part of its supply of turpentine and resin. On almost any sunshiny day in mid-winter when all nature has a lazy and indolent look and nothing seems to be stirring you can count that an average of $\$ 100,000$ is trickling down from the pierced 
pine trees into the little earthen pots at their base. The pine trees are "turpentined" for several years before they are cut. After a few years they lose some of their vitality through the process, but are still considered merchantable timber. The commercial turpentine and the resultant resin are procured through thousands of little, homemade stills located in every part of the commonwealth, and usually attended by negro help. It is one case where you may eat your cake and still have it, for the tree produces several times its cost in turpentine, then produces it again when cut up into lumber, and then, in most cases produces it again when the cut-over lands are sold for agricultural purposes.

The north central states figure a growing season of 110 days. The New England states figure on 120 days. The central states figure on 150 days. Southern California estimates from 238 to 300 days, while Florida figures on 348 growing days out of the 365 . It is this longer producing period that gives the state its great advantage over any other section of the country, and which will continue to be of increasing importance as the state fills up with growers, and the markets of the world feel the need of supplies to feed the oncoming millions.

The annual rainfall of Florida is 57 inches. The rainy season begins in June and lasts through September. During this period it rains every 
day. Throughout the rest of the year there are occasional rains, and they can be counted on to such an extent that it has not been considered necessary to irrigate. There are irrigation systems in use, but not one-tenth of Florida growers have found their use essential to successful crops.

Frank A. Munsey, the publisher, puts the case of Florida's dependable resources in this way: "Men are now fishing gold in Florida, not in mines, but in the forests, farms, fisheries and factories. Not all the gold that was found in Nevada and Arizona last year would equal the wealth that went to Florida for her fruits and vegetables, nor would the total output of Alaskan mines be enough to buy the cigars of Tampa and Key West. There are enough golden oranges and grape fruit in her groves this winter to pay back the price-five million dollars - that the United States paid to Spain for the territory, and the lumber that Floridians shipped from five sea ports in one year was sold for ten million dollars.",

You speak of Florida and think only of oranges, yet, while the orange plays a stellar role in the life of the state, it has long years ago ceased to be the only crop. Taking oranges from Florida would be like taking coal from West Virginia, or the steel industry from Pennsylvania, it would cripple, but not kill.

The largest singly-owned orange grove in the 
world is that belonging to King Bros., of Cleveland, $\mathrm{O}$. It is near Wildwood, and contains eleven hundred acres. This grove ships, not by the crate or the carload, but the train load. At Winter Haven, forty miles east of Tampa, are eleven thousand acres of continuous grove, probably the largest territory devoted entirely to citrus fruits in the world.

When you speak of potatoes your mind immediately reverts to Michigan, and Michigan surely does raise some potatoes, but, at Hastings just below Palatka there are ten thousand acres devoted entirely to Irish potatoes. These are ready for the market in March and April and command such fancy prices on the market that buyers from all over the country locate at Hastings for the season. Potatoes are shipped north by the train load.

Oranges cut a lot of ice, but-one little station in Hillsboro County shipped 974,000 quarts of strawberries to the epicures of the north last year, the price varying from 75 cents to 25 cents a quart. When strawberries get less than 25 cents a quart the Florida gardener quits shipping and turns his attention to more profitable things.

Oranges are in the lead in Florida, but-in the region around Sanford if from ten to twenty carloads of celery and lettuce a day is not shipped during December and January and February Sanford is fretful and peevish and thinks that things 
are dull. Down on the Manatee River the production is as great and the returns as satisfying.

Oranges are the principal item, but-over in Pasco County there are acres of covered tobacco beds and the tobacco raised in this genial soil and under the warm rays of a tropic sun is sold, much of it for a dollar a pound, and what is done in one spot of fifty acres can be done in fifty different sections.

The alligator has stood as the fright, the bug-aboo, the hob-goblin of Florida, just as the old-time mariner was taught to fear the great sea monsters that legend had pictured. The alligator has one distinct charactertistic that makes him stand out boldly, and that is the disposition to attend strictly to his own business, and let everybody else severely alone. You have to run after an alligator and run hard to catch him, in order to pick a fuss with him. Think of the alligator in commerce. Irrational. Yet the much maligned alligator, without any desire on his part, has become a potent factor in the marketable products of Florida. Throughout a thousand cities the most exclusive jewelry establishments and art stores display hand bags and pocket books and various novelties made from alligator hides, and these are used by fair ladies who do not dream that, in order to put these treasures within their reach a small army of alligator hunters pursue these wily creatures through the dismal and distant swamps, and 
can only capture them by great stealth and long practice. The alligator industry in a single year will yield $\$ 5,000,000$ in revenue.

The largest sponge industry in America is at Tarpon Springs, on the Gulf Coast, where two hundred and fifty vessels, manned entirely by Greek sailors, are engaged in this single industry. These daring boatmen and divers go from ten to fifty miles out in the gulf, and stay for weeks and months, finally appearing in port, down the little Anclote harbor, with ships laden with sponges. A regular auction market for sponges is conducted twice a week, much on the order of the tobacco "breaks" at Lexington and Cincinnati and other burley centers, and to this market come the buyers from all the metropolitan sponge houses. Tarpon Springs, along the fairyland bayou is one of the most picturesque and beautiful spots in the world, and strictly American in citizenship, ideals and architecture, but ten blocks away, if the traveler were blindfolded, and set down without a knowledge of his whereabouts, he would declare he was in the shadow of the Parthenon, for the sponge business is conducted entirely by Greeks; the shops, homes, costumes, vessels and language are all Greek.

You look for building stone in a hill country, but the deposits of that fine grade of building stone, Cochina, along the east coast particularly are almost unlimited. It is of a fine texture, a dull 
brown color, and is a shell formation, piled away there countless centuries ago by the fish, and just now being used by man to erect his palace.

These shell fish were a busy set aeons ago. The shell fish, the oyster, the clam, and others of the shelly tribe evidently made their home in the bed of the ocean that once covered where Florida now is, and there are layers six, eight and ten feet deep of solid shell, found at numerous points all over the state. These shells happen to fit into the modern demand for hard roads and they make a most excellent and durable automobile highway, so the automobilist of this age is traveling in exquisite comfort over the roads built for him back in the unrecorded ages of the shadowy past.

The spirit of progressiveness is shown in the fact that Florida has more daily newspapers than twenty-six other states in the Union.

Official figures from the State Board of Agriculture state that the average returns per acre from fourteen principal vegetable crops, on good land and bad, where carefully attended or loosely looked after, is $\$ 213.36$ per acre, ranging from $\$ 750$ per acre on celery, $\$ 395$ per acre on lettuce, $\$ 252$ per acre on strawberries, to an average of $\$ 67$ per acre on canteloupes and $\$ 43$ per acre on watermelons. Much greater yields are given in thousands of instances, but this is averaging all the reports up, shaking them down, and leveling 
them off so as to get a fair statement, unmixed with enthusiasm.

The value of Florida live stock, according to official figures, was $\$ 29,541,000$ in 1914 , and the value of poultry at the same time was $\$ 1,137,000$. The value placed upon dairy products for the same period was $\$ 4,130,000$. The total value of all farm products, including field, vegetable, garden, fruit, live stock, poultry, dairy and apiary products was officially given as $\$ 83,937,135$.

Forty-nine thousand two hundred seventy-five goats were wandering about over Florida's stretches of wild land at last reports, and 2,867,500 chickens were accounted for. A million goats, twice as many sheep and innumerable chickens ought to be raised. Their "upkeep" costs little. 


\section{CHAPTER IX.}

WHAT THE SOIL IS GOOD FOR.

THE first rush of settlement towards California in '49 was not because the soil of the Western Coast attracted the husbandman. The adventurous pioneer of that period caught the gleam of gold in the hills and cared nothing about what kind of dirt was on the surface. But in the decades which have followed, California's real gold mines, under the inspiration of Burbank and hardy tillers of the soil, have been found on the surface rather than under the surface.

The temporary effects of a rush of gold hunters or oil hunters may bring seeming prosperity, but when they have folded their tents and gone on to newer fields, the after-clap is disastrous.

The soil is the one criterion of a country's prosperity.

No less an authority than the Commissioner of Agriculture of Florida makes the statement that "Nowhere on the American continent can the industrious, right-living man find a better country, a more congenial climate or a more responsive soil; nowhere can he make as good a living and create a competence for the future with less labor 
and personal effort than in Florida, if he but observes the laws of common sense and ordinary business requirements."

That statement sounds like common sense English, coming from a public servant whose business it is to know things. It is made in good faith and after years of painstaking study of the varied soils of the state.

We are not so much concerned with the formations of the Eocene, of the Pliocene age, nor with the scholastic and technical distinction between Norfolk fine sand and fellowship soil. Let the geologists worry about those things.

What we are concerned with vitally is to answer the question so often and so insistently asked as to whether the sandy soil of Florida is fertile enough to raise anything, and in that discussion it is well to give, in a general way the various soils prevalent in the state.

You cannot always tell, in a cursory glance, what can be produced in a given spot. As illustrating this, the writer was bowling along on an accommodation train through Central Florida a winter or so since, and the usual number of passengers were lounging, or talking, or looking out the windows, or sleeping. It was our lot to be hemmed up in the smoker with the man who knew it all. He had an audience of three who listened patiently to his explanation that he had been all over Florida in the past week, and he couldn't see anything 
to it. Glancing out the window, he pointed his finger at the unbroken level of sandy loam along which we were passing, and asked with an air of finality if anybody could imagine ground like that, to which he was pointing, producing anything. The inevitable answer was "No." Just then something got wrong with the engine and we stopped for some time awaiting repairs. The passengers, as is their wont, piled off to walk around and see what was wrong.

It so happened that we were in front of the same kind of sand, and some men were working not far from the fence. The too-well-informed passenger leaned across the fence and asked one of the laborers what he was after. On being told that they were digging sweet potatoes the incredulous one persisted in a personal inspection, followed by a number of other curiosity seekers, and found the men with the hoes digging out bushel after bushel of large, plump, well developed sweet potatoes of unusual proportions.

It is folly to assume from generalization, or from knowledge of one part of the earth's surface, what can be produced in another.

The dirt that will cause a pine tree fifteen or twenty inches in diameter to shoot up in the air a hundred feet, and that will accommodate twentyfive of these monsters to the acre, must have sustenance of some kind hid away in its composition. If it brings forth rank verdure of one kind it is 
only logical to suppose that it will produce something useful if given the proper chance.

It is an adage in Florida that where the pine trees grow large, there is a favorable soil for citrus fruits, and so it has proven.

Outside the Northern and Northwest sections of the state, where red clay is common, the state of Florida is a vast expanse of sand.

Sand may be sand, and largely silicate, or it may be a sandy loam, capable of treatment. The silicate form occurs along the beaches just as along every other beach, and is not dealt with in a discussion of soils.

Careless observers have lumped the whole peninsula in one category, named it a sandy waste, refused to recognize any mitigating circumstances, and have hied themselves back to the place from whence they came, spreading the report of their investigations and flitting observations wherever a listener could be found.

Silicates are not very productive, and the flora along any beach is sparse. But, if a white looking sand can be made to produce a grapefruit tree and that tree has fifty boxes of large, perfectly developed grapefruits on its boughs, then, either "there ain't no sich thing," or the casual critic has made the mistake of judging a whole state by a square yard of surface.

Florida is covered with a mantle of sand. Back in prehistoric times old ocean rolled over its en- 
tire area. The history of this unknown era is written in great beds and deposits of shells, many miles in length and from five to ten feet in depth, discovered in parts of the state, and now turned to commercial account in making shell roads. After the waters had receded, the giants of the past, the mastodons, the animals now extinct, wandered for unknown aeons and passed off the stage of existence. In the phosphate beds are found the bones, not only of these, but of elephants, hippopotamuses, and other animals found only now on other continents. The geologist and the antiquarian find Florida interesting.

It was all, once, the sandy bottom of a great ocean. It is still sand, but centuries and aeons of time have seen the ever recurring round of spring and summer growth yield to fall and winter death, until the falling leaves and decaying vegetation have formed over millions of acres a fruitful sandy loam. Where the waters still cover the sand there is unfailingly a rich muck soil that is very productive.

Undeniably, sand is very common in Florida. It is so prevalent and so persistent that soil experts have analyzed it and classified it to a gnat's heel, and have stood it in long, formidable rows and given it big, foreign looking names, but, after all, it is only sand, whether the scholars call it Norfolk sand, Norfolk fine sand, sandy loam, calcareous high hammock, low hammock, Fellow- 
ship fine sandy loam, Parkwood, silty clay loam, coastal, beach, muck, peat, or whatever other category it may come in, it is still sand, sand, sand.

For practical, every-day purposes, the soils of the state, or rather, the sands, are divided into four or five commonly known classes, each adapted to certain forms of products.

"High Pine" land is the lighter sand areas that prevail more largely in the central parts of the state, and where there are elevations, though not limited to such areas. The natural growth of such soils is the stalwart, long leaf pine tree. These lands are usually free from swamp or are easily drained. Such soil has been found, after extensive experiment, to be best adapted to oranges, grapefruit, lemons, limes and the members of the citrus family. Many vegetables can be profitably raised on high pine land, particularly tomatoes, peppers, squashes, sweet potatoes, peas, beans, etc., but it is not adapted to Irish potatoes, celery, or products requiring a heavier soil.

"Hammock Land" is a general term applied to large bodies of land where the soil is as light as the high pine, but the natural growth consists of a smaller variety of pine tree, and this land is frequently covered with tall grasses. There are two kinds, "Light Hammock," applied to sandy hammocks with a light growth of native vegetation, and "Low Hammock Land" with a heavy clay texture, and with a native vegetation of live oak, 
water oak, gum, black oak, and other water-loving trees.

Hammock lands, both light and low, are cultivated in all parts of the state, successfully, and in many places are found to yield well in corn or sugar cane and vegetables, but are not so well adapted to citrus fruits.

"Muck" is the soil found where water still covers the earth or where for ages it has covered the surface until drained. The Everglades are the great depositories for muck soil. Large areas on the East Coast along the seaboard are noted for their muck lands. In other sections of the state where swamps and low ground are to be found, there is a fine quality of muck land, which, when drained, is much sought after by growers on account of the readiness with which it produces vegetables.

Muck is not only strongly impregnated with decayed vegetable matter, but it has an appreciable mixture of animal matter as well. It is heavy, usually dark, solid, and often soured to such an extent that lime and other ingredients have to be mixed with the soil to sweeten it up for farming purposes. It is the residual of water-covered ground which throughout unknown ages has had rank vegetation and which has profited by the decayed matter. Wherever this soil has been scientifically tried out it has brought forth abundantly. It was on account of experiments with muck, and 
the knowledge that the Everglades were the great depositories of muck soil that the agitation for the drainage of the Everglades originally began.

Underneath all of these soils is usually found, at a depth varying from eighteen inches to five feet, a good quality of clay. This clay is, in many sections, so hard and impenetrable to water that it is known commonly as "hard pan." It can easily be seen that such an underlying earth is of great value to agriculture because it holds the water and keeps it from sinking right through to greater depths. Florida has its rainy season from June to September. During these months there is rarely a day but brings a heavy rain. Often they are long continued and the precipitation is phenomenal. In the winter, however, at the time when most of the state's best crops are maturing and ready for market, there is little rain. If it were not for the underlying clay which persists almost over the whole state, holding the water near the surface and refreshing the roots of trees and growing things when the top is very dry, it would require extensive irrigation systems to raise anything worth while in the state. As it is, there are many small irrigation plants used, but comparatively few when the number of growers in the state is taken into account. Whole sections will show but one or two farmers who have invested in an irrigation system. There are few winter growing seasons when the moisture retained by the 
clay subsoil is not sufficient, together with the occasional rains, to mature good crops. Irrigation systems are rather a "safety first" proposition in Florida, a sure shot preventive of drought rather than a generally recognized necessity.

Between these few main divisions of soil there are many gradations and varieties, characteristic of different localities and dependent on the lay of the land, the depressions, the elevations, the water courses and other conditions.

There are coarse sands and fine sands and loamy sands and sands heavily permeated with clay, or vegetable, or animal matter, but sand is the prevailing soil, whatever its geological or scholastic classification, it is still sand.

If sand is sterile and will not produce, then Florida is a desert, and the reported crops are a myth. If, on the other hand, there are actually heavy laden groves and bumper yields of almost every known vegetable, then sand must be fertile.

One characteristic of Florida soil, which pertains in a degree everywhere, is the quick diversity in a very small compass. Within a few hundred feet an emphatic and radical difference in soil shows. One will yield to culture readily. The other will not. To the casual observer, both may look nearly alike.

It has always been so in oil and gas territory. A gusher may be found in one spot and fifty feet 
away a duster will come in. In Florida the changes are sudden, and a barren spot, usually of small dimensions, will occur right alongside a fertile piece of ground.

It used to be supposed that the wide stretches of flat country with few trees, and covered with a dense coating of palmetto bushes, was a barren waste and incapable of profitable cultivation, but the wonderful truck gardens of the Manatee country are known in all the markets of the United States.

The same cultivation and treatment that has made this wilderness to blossom as the rose, to bring forth fruit in abundance, has been extended on down the gulf and miles below Sarasota the wilderness is being conquered and harnessed to the uses of men, and great plantations are laid out.

Yet, the region naturally is smothered with a rank and tenacious growth of palmetto.

If some Nature wonder worker would invent a profitable use for the palmetto, millionaires would be made in Florida over night.

The most delicate and innocent looking palmetto that rises not over twenty-four inches above the ground, has a root as large and as difficult to grub out as the giant oak or beech, and when there are vast mazes of palmettos growing closely together, their roots intertwined and bent in such a conglomerate mass that nothing this side a dynamite 
bomb seems adequate to meet the situation, they are a problem in hard work. As a matter of fact, the giant powder and dynamite methods are being used with good results. Large explosive companies have planted branches in Florida and are showing the farmer how easy it is to get rid of the pestiferous palmetto, an acre at a time.

The palmetto is as ungracious as a bad habit about letting go, but once loose, it is loose for good. 


\section{CHAPTER X.}

THAT FERTILIZER QUESTION.

AND now we are squarely up, face to face, with the question as to whether or not anything will grow in Florida without fertilizer.

Broadly speaking, no.

What are the farmers-the ambitious ones-in all the states north of the Mason and Dixon line, and, for that matter, south of it, doing from November until March?

The lazy ones are sitting around the fire resting their dry bones and talking about the weakness of our political leaders and the mistakes of Moses. The industrious ones, who use their brains as an asset in their business, are strengthening the soil on their places. They are hiking around the country getting manure and other forms of fertilizer and scattering it over the land-renewing it. Some of them who have damp, soggy, sour land, are throwing lime over it to sweeten it up.

If they do not use fertilizer will they have a crop? Yes, but half the farms in the Central States today are run down and nonproductive because lazy and shiftless farmers who depend on Providence and not on muscle, fail to build them 
up with fertilizers. These farms produce, but only in a half-way degree, and get worse every year they are cultivated. Is fertilizer necessary in Illinois and Minnesota and Virginia? Yes, if one is going to make farming pay. If he doesn't care it is not. Something will grow. Dog fennel and rag weed will grow without fertilizing, but corn and potatoes will not.

The situation is the same in Florida with these two variations. Very little will grow without some fertilizer, except in the richer muck lands. But a reasonable degree of fertilization brings such results in production that nobody this side an arrant fool would withhold the little attention necessary to produce the right sort of a crop.

Fertilizers are practically essential to production in most of the state. But the same hand that made the sand, placed large beds of phosphate right over against the sand, and commercial fertilizer is largely made from phosphates. The phosphate has to be chemically prepared, but it is the basis of fertilizers as used in the extreme South.

The Lord furnished a warm, even, well-tempered climate, just right for growing stuff ; he furnished a soil that could be easily induced to raise big things; he provided enough rain to keep things fresh; he set the phosphate beds conveniently around, and said to man, "Go to work, here are all the conditions for an abundance. Now, work or starve." 
Barnyard fertilizer is as valuable in Florida as any place else and costs as little. Commercial fertilizer costs from $\$ 20.00$ to $\$ 40.00$ the ton, depending on markets and conditions, and adds, in general, about ten per cent to the cost of growing vegetables and fruits. It adds from seventy to ninety per cent to the productiveness of all sorts of vegetation. Who would decline to make the investment at such a rate of interest?

The cost of fertilizer is a negligible quantity as compared with the results that come from its use. The grower who uses it, puts his money and his labor out at compound interest, and then has advantage of the ordinary usurer by raising two or three crops on the same piece of ground in the same year.

If the trucker decides to devote a piece of land to tomatoes, he plants and fertilizes properly the latter part of December or early in January. In March he is shipping to the northern markets. When tomatoes are done for he decides to raise watermelons, and in May he is shipping watermelons to the markets. When the season is over he puts in cow peas, or some of the hay crop like Natal hay, and in the fall he has a good yield of hay or some forage crop. He uses this, or sometimes turns it under to enrich the ground; but three crops on the same pieces of ground in one year is common. What wonder, then, that fertilizing is necessary? It would be advisable on the 
richest soil on the globe. In Florida it is essential to growth.

One great trouble with the transplanted farmer from some sections of the North is that he has to wholly reconstruct his ideas of agriculture before he can make a success of it. If he has been accustomed to scattering his efforts over a hundred and sixty acres in Tennessee or Missouri or South Dakota, and especially if he is one of those commonly known as "hill billys" who has been content with raising a little corn and a hog or two, and resting during most of the year, he had better rearrange his ideas of cultivation, or steer clear of Florida. Intensive cultivation of a small tract is the rule in the state, and intensive cultivation means hard work and knowing how to make things grow. Hundreds, yes, thousands of instances can be given of ten-acre tracts properly cared for which produce as much as the average one hundred and fifty-acre farm in cooler latitudes, but the results are obtained by intelligent work, and not by trusting to Providence or tenants.

Fertilization, in a modest way, spells success in Florida, if intelligence and labor accompany the fertilizer. Ten or twenty acres is a lot of land if the grower is going to get acquainted with each individual weed, but when he does it he is on the high road to competence. Laziness and shiftlessness are at a discount the world over, but there are some countries where they do not show glar- 
ingly. In Florida they stand out like a wart on your nose.

The exploitation of certain crops in certain localities might lead one to suppose at first thought that these sections have a soil of such texture as to give a practical monopoly on these products. Such is not the case. It means, rather, that special attention has been paid to certain marketable articles in a given locality, and that growers in the area have joined efforts on a few leaders. This is sometimes beneficial on account of economical handling, crating and shipping and sometimes the soil in a locality is unusually genial to one vegetable or another, but there may be a multitude of places in which the same results might be obtained if the same efforts were made.

By way of illustration-Orange, Lake and Polk Counties in the highland lake region are looked on as advantageous locations for citrus groves, and these do flourish; yet, on the high pine lands near Clermont, right in the heart of this citrus belt, we have seen tomatoes that yielded $\$ 800.00$ an acre; squashes that produced $\$ 600.00$ an acre; rutabagas of enormous size, abnormally large sweet potatoes, carrots, radishes, peppers, egg plant, and a dozen other vegetable wonders. Yet this region is largely and properly the home of citrus fruits.

Because a high grade of tobacco is grown in Gadsden County and not much attention is paid to it elsewhere in the commonwealth, does not 
imply more than that it has not been attempted in other localities.

Because Sanford is known as a celery and lettuce center does not mean that soils in other parts of the state are not equally well adapted to its growth, for it is produced in scores of places. A hundred cars of celery a season are shipped from fields on the edge of the City of Tampa.

Irish potatoes are a big item in the agriculture of a part of the East Coast, but geography has nothing to do with this fact. Similar heavy, muck soil all over the state will yield the same results.

The heavier crops of corn are raised in the Northern Panhandle, but corn is produced in every county in Florida.

Polk and Bradford Counties have the ascendency in strawberry production, but Bradford County has as genial a soil, and they can be produced in every part of the state.

Given perfect climate and moderately good soil and production is only limited by the wisdom and energy of the people who do the cultivating.

The Canadian farmer in the little growing space open to him between May and September devotes his energies to wheat, because wheat is possible and wheat pays. When the ides of September approaches, the Canuck begins to batten his house and patch up the crevices around his barn, for he will be banked up with snow for six months. The Florida farmer has four growing seasons instead 
of one. He has a hundred opportunities instead of applying himself to one crop like wheat.

There is something planted and something harvested every month in the year in the Sunshine State.

This was not so a decade or so since. Chance brought about the diversified farming of the state. Up to 1895 Florida was supposed to bring forth oranges and nothing much beside. Only a few years before the freeze a grape fruit tree was looked on as an interloper and was promptly cut down and the wood used for fence posts. The freeze compelled trial crops of all kinds. It opened the eyes of the native people to the wonderful possibilities before them. It remade Florida. Nothing now is impossible.

All you have to do to start some fellow in a profitable line of production is to intimate to him that he cannot raise it in Florida, and somebody begins raising it at a profit.

Providence has furnished sand, rain and sunshine. If man will help out with a little energy and some fertilizer and use his good judgment as to what to plant and when to sell it, Florida is good enough. 


\section{CHAPTER XI.}

\section{WHAT CAN BE RAISED PROFITABLY?}

We do not want to be accused of endeavoring to "take in too much territory," as the Irishman did in the saloon, but it may be broadly stated that any vegetable, fruit or grain that can be produced any place else in the world, can be raised in Florida.

The climate is so varied, the soil so diverse, and conditions of growing so favorable that, to some degree or other, anything that is growable will grow in Florida.

Of course they will not all make profitable producers.

One feature must, however, have credit, and that is that the growing season lasts practically throughout the year. A reasonable rotation of crops will produce two, three, and sometimes four harvests on the same ground.

The most skeptical must admit that these conditions favor profitable agriculture and that if there are not paramount obstacles which cannot be overcome, Florida ought soon to be the most profitable farming area under the sun. Its sponsors do not hesitate to make this sweeping prediction.

Profits on products depend primarily on soil, 
and climate and markets, but secondarily on the cost of production, which involves the valuation placed on the land itself.

It does not require a mathematician to arrive at the conclusion that, if a profit can be realized on ground that costs one thousand dollars an acre, a better margin will be shown on ground that costs $\$ 150.00$ an acre, and Florida has very little soil that is selling at either price.

Granting that there are 19,000,000 acres of tillable ground in the state, it will be many years before this is crowded, even with the spirited influx of home-seekers shown in recent years. Not more than 2,000,000 acres are under consistent cultivation at this time. Large cattle ranches are used for grazing purposes, and since the stock is dependent on native grasses for sustenance, these ranches might reasonably be added to the farming territory, but they are not tilled.

When you compare Florida's present population of a little over a million, with the dwellers around Wall Street who number nearly five million, it is easily seen that there is no crowding. One of the long cherished dreams of our philosophers and statesmen has been that the dense congestion in our over-populated cities might be relieved by a movement to spread out and get back to the soil. We have too many consumers and not enough producers. This hope is possible of fulfillment if a message can be gotten through to these cooped- 
up millions that there are broad fields in the further South beckoning to them.

Land in California, adapted to citrus fruit culture, varies in price from five hundred dollars to two thousand dollars an acre. California has about the same wet and dry problems that face Florida, and has a soil not unlike that of the latter state in that it is sandy and light. California's growers regard the price of raw land in their state as reasonable, and agriculture on the Western Coast shows a healthy profit, although the producer is two thousand miles further from the leading markets than his competitor in Florida.

A fair statement of average acreage prices in Florida would be fifty dollars an acre. Where it is remote from transportation, uncleared, covered with jungle and distant from population centers, it can frequently be had for twenty-five dollars an acre, and less, but lake fronts and well located citrus and vegetable lands sell as high as $\$ 150.00$ and $\$ 200.00$ an acre. Wild lands, particularly what is known as cut-over lands, in large bodies, without improvement or settlement may be had at a lower price, but are not advisable purchases for the small buyer because the necessary work of development cannot be done by a single small owner. These are community matters and must be done by a combination of interests. The cheaper tracts involve important improvement work and community upbuilding to make them 
practical. The large development companies, the colonies, the organizations, the land companies, have frequently been caustically criticized for the price they placed upon their lands; but the critic has failed to consider that the organization has sometimes spent a modest fortune in general development in paving the way for practical farming before they offered an acre of land for sale.

If California land sells at an average of say, $\$ 1,250.00$ an acre, and a similar soil in Florida sells for an average of fifty to sixty dollars an acregranting as good a climate and a reasonably fair soil in comparison, manifestly the argument is altogether in favor of the Southern state.

The cost of clearing where the palmetto is in its greatest glory may run as high as thirty to forty dollars an acre, but in sections where the palmetto is sparse, and where scrub oaks or pines are prevalent, it can be done for fifteen dollars to twenty dollars an acre.

To get fairly at the question as to what a man can profitably raise in Florida requires attention to a number of items. Distorted views sometimes creep into the folders and booklets of promotion companies and colonization leaders, and, while these are infinitely more reliable than they formerly were, the writers, in their enthusiasm, are apt to take isolated instances of heavy production and draw a moral from these alone.

For instance: A man in a husky little com- 
munity not far from Tampa Bay, reported that he had a watermelon weighing fifty pounds on his table for Thanksgiving. Investigation proved that he did have such a melon and at this unseasonable time, but inquiry also developed the fact that he had grown but one melon, and it would be unwise and therefore misleading to state that "this section is noted for the abnormal size of its watermelons." If he could raise one melon, he could raise more, of course, but general conclusions should not be drawn from solitary cases.

An entire book could be filled with authentic instances of big profits made in given localities, on any of the prominent products of the state, but the faithful chronologer must hit the low places as well as the high places, or, at the very least, confine himself to a happy medium that comes within the easy realm of ordinary accomplishment.

Here is an actual case: A Kentuckian had a fine - orange grove in the center of the state not far from Ocala. He entrusted it to careless tenants. From lack of attention, it run down. He tired of its ownership, reported the grove business as unprofitable, and sold his possession at a loss. A wide-awake, practical grower bought it, restored it to its former perfect condition, watched it carefully, and in three years showed from his books that the grove had paid for itself and had $\$ 9,000.00$ cash to its credit. If we had reports from the two owners on the same grove, to which would we give 
credence? It was a failure, and it was a success. It was simply a difference in the handling.

If the average successful manufacturer should shut down his desk, leave his plant, and go off to the seaside and trust to "luck" for dividends, he would go "broke" and ought to.

Eternal vigilance is the price of many other things besides liberty.

Whatever else is produced in Florida, the state will probably stand or fall on its citrus fruit reputation, since the soil and the climate combine to make the citrus family thrive here as nowhere else.

Speaking of citrus fruits reminds us of a good old county judge, from one of the states up North, a well-informed man in many ways, but botanically deficient.

He said, "I have been around this section quite a little in the last day or so. I have seen the oranges and the grapefruit, and the tangerines and lemons, and now I would like you to take me out to some grove and show me one of them there citrus fruits that you have been talkin' about." In as delicate a way as possible, so as not to give offense, we reminded him that he had already seen the citrus fruit.

Florida shipped about nine million boxes of oranges and grapefruit for the season of 1914-15. War conditions had so broken up the markets of the country that normal prices did not obtain. Under average circumstances, from year to year, 
the grower may expect an average of at least $\$ 1.50$ a box for oranges, and $\$ 2.00$ per box for grape fruit. Florida oranges are universally considered sweeter, juicier, and of a more delightful flavor, than any competing orange. On the Boston market of last year, car loads of Florida oranges averaged from $\$ 3.60$ per box to $\$ 4.27$ per box.

Prices in the retail market, naturally, are very much higher at times, it being no uncommon thing for grape fruit in April and May to go from $\$ 4.50$ to $\$ 8.00$ a crate.

In the Winter Haven district, where the citrus industry has reached a high state of development. as much as fifty thousand dollars has been offered for twenty acres of mature growth, and the offer refused. The grove in question has averaged almost $25 \%$ on fifty thousand dollars for many years. Nearby is another grove containing less than eight acres, which has yielded a net profit of over four thousand dollars annually to its owner for the past five years, in 1913 the earnings on this small grove being $\$ 7,000.00$ net.

Oranges have been looked on as a staple; grape fruit as a luxury. Grape fruit is fast passing the point of luxury where you see it only on dining cars, and in high-class restaurants, and Florida is the only state where grape fruit is generally and successfully raised.

In conversation with a man nationally known, and of wide business experience a year or so since, 
we questioned his wisdom in setting out such extensive grape fruit groves, and asked him if he did not fear over-production. His reply was to the point, and contained keen judgment and foresight. He said, "We are building for the future. There are ninety million people North of us; seventy-five million of them never yet tasted a grape fruit. When the grape fruit becomes known to the many as it is now known to the few, you might plant all of Florida in grape fruit and by no means satiate the public appetite for it." While the orange is seen in the hands of even the poorest child just as candy is seen, grape fruit is not yet known to the great mass of the people, yet grape fruit has no equal as a mildly acid tonic, or as an appetizer. A campaign of popularizing this fruit would pay better than any investment the state could make, and would be followed by such demand that the groves would not be able to furnish the fruit.

One of the attractive qualities of grape fruit, from the standpoint of marketing is its stick-to-itiveness. It just seems to hate to let go. The orchardist of the North who grows apples has to pick them at a certain time or they relieve him of the necessity by falling off. Even before this, the busy little worm gets in his work and unless proper spraying is done, half the crop falls untimely. The citrus fruit grower may have ripe grape fruit in November. He may decide that the market is not favorable, and if so he can leave his crop on the 
trees until December or January, or February, or March. He can even wait until April, and only a small percentage falls off. Then there are late varieties coming into extensive cultivation which ripen in February and hang around on the trees until June, or even later. Experimentation and scientific treatment have gone far enough to almost establish grape fruit as an all-the-year product.

The high pine, or hammock ground best adapted for citrus purposes, costs, on the average, $\$ 60.00$ an acre. It would take in most instances, $\$ 20.00$ an acre to clear it. An average of 49 trees per acre are set out. These cost from fifty cents to one dollar per tree, averaging, say, seventy-five cents. The fertilizer necessary to their start costs, perhaps, ten dollars an acre. The labor and care at the first, twenty dollars an acre. It is four years before the young trees begin to show any returns, and in the fourth year the yield is small. In the fifth year the grape fruit ought to yield a box per tree. In the sixth year from two to three boxes. If this grape fruit is marketed to advantage at something like $\$ 2.00$ a box, an acre will yield $\$ 98.00$ the fifth year; $\$ 298.00$ the sixth year, and from that on the production increases gradually.

Reports of all kinds come from different sections where citrus fruit is grown. It is no uncommon thing for the growers in every part of the state to report a net profit of $\$ 2,000.00$ and 
$\$ 2,500.00$ on a five-acre grove, eight or ten years old, and from that up to $\$ 4,000.00$ after deducting customary incidentals and labor. The question is frequently asked, and it is a pertinent one, if the Northern citizen who desires to spend his winters in Florida can afford to own a moderate sized grove, coming to the state for perhaps three winter months and leaving the grove for the rest of the year. It is about as safe a proposition for a man to go off and leave alone as any investment that a man can make and not continually watch. If the fruit is marketed in the presence of the owner, and the trees given proper care and fertilization, very slight attention need be paid to them during the balance of the year, although a limited amount of looking after at intervals throughout the spring and summer will pay, and this service can be had in every community for a small sum.

There is no set rule as to the number of trees to plant to an acre, some planters putting in seventy, but the majority setting out not more than seven rows of seven trees each to the acre. There is no fixed rule as to fertilizer. One expert authority figures $\$ 6.00$ per acre for the first year, $\$ 12.00$ for the second year, $\$ 18.00$ for the third year, running as high as $\$ 40.00$ for the eighth year, but immediately qualifies this statement by saying that half of this amount ought to do.

Bearing groves are sold on the market at from $\$ 1,000.00$ to $\$ 3,000.00$ an acre. The price asked 
for any given grove depends almost solely on how well that grove has been cared for.

Slight cold spells do not affect citrus groves adversely. A cool spell, and even a slight frost is looked on as being an advantage to the ripening fruit, but, cold spells and reported blizzards are not thoroughly enjoyed by the man with a big crop on his trees. Some groves in the central and northern parts of the state have been for years, provided with stoves and other forms of heating apparatus to provide against a sudden drop in the temperature, but these are not often used, for as a matter of fact, outside of a few sections like Crescent City, there are not many groves in the northern part of the state.

As a matter of downright pleasure and satisfaction, the care of an orange grove is one of the most pleasing diversions that a man can have. It is one of the most reliable forms of investment, if it has consistent and scientific attention.

If the cultivation of an orange grove brings health and recreation, and satisfaction, it has paid for itself; but if it also brings dividends, and a healthful bank account it has paid better.

Tangerines are among the most attractive of the fancy oranges grown. They are known as the kid glove orange, and always have a ready sale.

Kumquats are junior members of the orange family. They are cultivated more as ornamentaltrees than for their commercial value and are only 


\section{WHAT TO RAISE PROFITABLY}

rarely seen in the markets of the North. They deserve and would repay much wider attention.

Except in the extreme southern part of the state, lemons and limes are cultivated in but a limited way. There is no inherent reason why large acreages should not be devoted to these very popular fruits, for they are in great demand at soda fountains and in the homes all over the nation. Their culture will bring satisfying returns. 


\section{CHAPTER XII.}

THE STORY OF THE ORANGE.

THe orange first saw the light of day in the impenetrable forests of tropical India, in the Valley of the Ganges, under the shadow of the Himalaya Mountains.

That was a long time ago measured by the days of the years of our lives, and yet not long as reckoned by the age of the grape, the olive, the fig and the pomegranate, all of which are spoken of in Bible history, while the orange is not; from which we conclude that the rise of the orange was within the time of the Christian era and that it is not over two thousand years old.

In process of time the natives of India brought the orange out from those dense, sunless stretches of pathless jungle, out into the open where sunshine and care developed it. The tree grew in size and the branches spread, the buds thickened and the roots went deep into the nourishing earth. Gradually, the fruit took on the rich golden color absorbed from the sun.

But this was the work of centuries. It took close study and experimentation by many people of many nations to bring it to its present state of perfection. In the 400 period it reached Europe. 
Later we catch a glimpse of it in Central China. Then it spread to Java. In time it reached Spain, and in the sixteenth century the Spaniards brought it to the West Indies and to Florida. The first orange trees were probably brought to St. Augustine in the year 1565 by Pedro Menendez de Avilles, who arrived from Spain with a complete colony of artisans, farmers, priests and soldiers.

The Spanish race, however, has never been an agriculture loving people, but rather were their ambitions toward world dominance; to the subjugation of nations, and to loot; to which end they bent their plow-shares and pruning hooks into swords. So, when we got Florida from the Spaniards, a hundred years ago, they had done little to develop this important industry in that state, which, more than any part of the world from the standpoint of soil, climate and rainfall seems made for orange growing.

In all these multiplied centuries it was necessary to discover that good oranges could not be reproduced from the planting of their own seed. It took years upon years to learn that the seed of the sour orange, the lemon or the grape fruit must be planted and permitted to take root for two or three years, then the bud stock of a perfect producing orange tree had to be grafted onto these roots, and, at the end of two more years of nursery growth, under scientific treatment, the perfected tree, then from five to seven feet in height, was 
ready for transplanting to the grove. This, in time, became the "pedigreed" tree, just as the live stock grower has his pedigreed stock of the highest producing strains.

And, as the years have come and gone, we have come to realize that the food elements of the orange are greater than those possessed by other kinds of human food. It seems as if nature, after practicing on all other foods, at last attained perfection and distilled inside the cover of the orange completed results. The orange is nutritious, exhilarating, appetizing and refreshing. It is a tonic, a blood purifier and a bone builder. In it are blended mineral alkalies, organic acids, sugar, phosphoric acid and iron. All these are essential to the highest development of good health and enable the user to live beyond the three score and ten limit.

Henry Abbey, a business man, philosopher and poet, has given to the world a pleasing little poem on the use of the tree, reproduced herewith:

What do we plant when we plant the tree? We plant the ship, which will cross the sea,

We plant the mast to carry the sails,

We plant the planks to withstand the gales,

The keel, the keelson and beam and knee, We plant the ship when we plant the tree.

What do we plant when we plant the tree?

We plant the houses for you and me, We plant the rafters, the shingles, the floors, We plant the studding, the lath, the doors, 
The beams and siding, all parts that be, We plant the house when we plant the tree.

What do we plant when we plant the tree?

A thousand things that we daily see,

We plant the spire that outtowers the crag:

We plant the staff for our country's flag,

We plant the shade from the hot sun free,

We plant all these when we plant the tree.

And to this another poet, philosopher, business man has added a few lines which fit in very nicely with those of Henry Abbey:

What do we plan from the orange tree?

We plan a fortune for you and me:

We plant the fruit that heightens our gains,

The food that cures us of aches and pains,

That settles our debts and makes us free,

All this we plan when we plant this tree.

What do we plan from the orange tree?

A round of comforts for you and me,

A home, an auto, nice trips and elothes,

And all the pleasure that money bestows,

Together with voyages over the sea,

All this we plan when we plant this tree.

What do we plan from the orange tree?

We plan for old age to be care free,

Our four score years o'er crowded with bliss,

Our trees to bloom and seldom to miss,

And never a trouble for us to see,

All this we plan when we plant this tree.

Yes, Mr. Abbey forgot the greatest tree of them all, for ships made of trees are submarined and sunk, or they strike icebergs and go to the bottom. 
Houses built of lumber from trees burn, but the orange tree goes on unceasingly. No fruit tree compares with it as to hardiness and length of life. If an apple trees passes the half century mark it is so notable an event as to occasion comment, but in Rome there is an orange tree that has reached the remarkable age of 716 years. It is split and riven by time, but its branches still tower skyward. In France there is an orange tree with the record of 463 years, and it stands sturdy and staunch, with promise of reaching a "ripe old age."

In Spain are orange groves 400 years old, one tree of which has been growing for 632 years, with no serious signs of decay.

No less a personage than Solomon said, "A good man leaveth an inheritance to his children's children." If the orange tree had been known in Solomon's time how earnestly he might have recommended it, because, in planting an orange grove we are doing the most permanent work of a commercial character that is possible for us to accomplish. We not only plant for ourselves but for our children and for their children.

The bountiful yield of the orange tree is not fully understood or appreciated. In the Azores is a tree that produced 20,000 oranges in one season. In Europe 5,000 were picked from a tree. In Lake County, Florida-to come nearer home-a grower gathered 6,000 oranges from one of the six hun- 
dred trees that comprise his grove, and he realized $\$ 97.00$ from the one tree in one season. The banner yield in Florida from one tree was 10,000 oranges. There are few like it. It is a tree sixty feet high and four feet in diameter.

When the orange is golden ripe in November and mingles with the green of the leaf on the trees, it is the most pleasing sight. Not only is it a dream for the artistic eye, but the commercial aspect is equally appealing. The golden fruit is suggestive of golden returns. Oranges hang on the trees, if desired, all winter long, the owner shipping when the market suits him best.

There is another yearly sightseeing occasion in an orange grove that is memorable. It is at blossoming time in February, when the air is suffused with the most delightful odors and the snow white bloom is wonderful in its wax-like perfectness. No perfume in the world is so sweet. The richness of the odor attracts the honey bees, and they help in the process of fertilization.

In countries where labor is cheap, as in India, for instance, where wages yield the pitiful sum of fifteen cents per day, they gather the surplus blossoms as they fall from the trees, spreading them fresh every day over wax that absorbs the odor, later treating the wax to an alcohol preparation that in turn draws the odor from the wax, and this simple process gives to milady the high priced and exquisite perfumery she loves. 


\section{CHAPTER XIII.}

THE GROWERS GOT WISE.

IN days gone by the orange pickers knocked the fruit from the trees with poles, bruising it and causing its premature decay. They improved upon that plan by pulling it from the limb by hand. Now, with a ladder, a sack and clippers, the fruit is cut from the limb and decay averted. Oranges are sorted by pouring them into a hopper, from which they run down a trough and over a revolving belt that has holes in it to fit the different sizes, which drop into their respective canvas lined compartments, and are then boxed for shipment. There are 80 large sized oranges in a box. They vary in size up to 250 , the average being 176 to a box.

There has been constant growth in the intelligent development of citrus fruit growing in Florida. The hand never touches the fruit, and the sanitary conditions could not be more perfect in the handling of human food. At the packing house it is sorted, washed, dried, polished, wrapped in papers, the bare hand never touching it from tree to table.

After the growers of Florida had their eye teeth cut, much as the tobacco growers of the Cen- 
tral States did, and after they found that the buyers were parcelling out districts to each other and that there was, in reality, no competitive buying, they got together and organized the Florida Citrus Exchange. This is the most effective factor in the state in the profitable handling of fruit.

This organization keeps the fruit flowing from the state to the Northern market with a steady hand, knowing exactly what each market in each of the consuming centers can utilize, and never overstocking a distributing center so as to pull down the price.

Just before the Citrus Exchange was organized growers were receiving as low as thirty cents a box for oranges, because the buyers had formed a pool and stipulated the price they would pay. Two months after this organization started in, commission houses raised their prices to $\$ 2.00$ a box. 


\section{CHAPTER XIV.}

PEACHES PAY, ALSO STRAWBERRIES, WATERMELONS AND CANTELOUPES.

THE Georgia peach (not Ty Cobb), has been so popular and so profitable that the world has overlooked the fact that Florida is congenial in soil and climate for raising peaches, and has engaged quite liberally in proving her claims as the coming home of the early peach. Peach culture has had new impetus in the past few years and has been instituted in all parts of the state, but more particularly in the northern counties.

While the average life of the peach tree is not long, it is a fast liver while it is at it. The peach tree's life is not more than seven years, on the average, but it begins to produce early, a straggling crop showing in two years. In the third year the crop is appreciable and marketable. In the next four years it is abnormally large. After that the peach tree goes into a decline.

The advantage of peach culture is that it gives variety to effort. The stock costs but little. They are set out thickly-108 to the acre-and very frequently are planted between the rows of citrus fruits while the young grove is maturing, and in this way are a big asset at little cost. Fifteen to 
twenty dollars an acre will give them thorough cultivation, half that amount will supply fertilizer, and, if the seven years' life of the tree nets $\$ 40.00$ per tree, as has been frequently done, this means $\$ 4,320$ per acre or $\$ 43,200$ for a ten-acre peach orchard for the seven years of its active life. The figures would look incongruous if practical peach raising had not proven that it can be done.

High pine, high hammock, or well drained low hammock ground is adapted to peach culture if the land is free from swamp. Florida peaches being naturally earlier than the Georgia crop, bring a fancier figure on the market, running from $\$ 2.00$ to $\$ 6.00$ per crate.

Apples are not attempted in Florida, except in the northerly sections, and then not on an extensive scale, because they are produced so largely in other states, and the modern storage house keeps them throughout the entire year. Pears, plums, figs, apricots, cherries, and all the common fruits of the central state are found in Florida.

\section{STRAWBERRIES.}

The epicure of the effete east used to look on this table delicacy during the winter months as a viand for the gods, because only a very few were raised, out of season, and these in hot beds, and at great cost.

Now, every grocery and fruit stand displays 
strawberries in the snow storms of January almost as freely as in the sunshine of June.

The answer is-the Florida grower, and the ice packed carton.

Strawberries require lots of moisture. They thrive best in low, sandy soil, with plenty of vegetable matter mixed in its composition. Florida has taken front rank as a strawberry producer for the unseasonable and the early markets. Twenty counties raise them profitably. As before stated, one little shipping point in Hillsboro County has shipped as many as 974,000 quarts in a single season. Under favorable culture and reasonable market conditions they bring from $\$ 750$ to $\$ 2,000$ per acre. They are packed eighty quarts to the box, in iced refrigerator crates and shipped altogether by express, usually on through fast express trains that make passenger train time. The cost is heavy, but the price ranges from 85 cents a quart to as low as 25 cents. When they run much below the latter figures shipping ceases and the trucker turns his attention to the next crop. The Florida strawberry is large and of a beautiful color and fine fragrance, but they are hardly so sweet as the northern berry. The man who devotes himself to strawberries and who has the proper sort of soil, usually counts on three months of unduly active work during the year and a good bank roll, so he can feel free to do what he pleases the rest of the time. 
WATERMELONS AND CANTELOUPES.

Before the day of Southern shipping for early use the watermelon harvest of the central states occurred about the middle of July. Today the country has become almost satiated with melons by the nation's birth day. The first melons on the Northern market come from Florida. A little later Georgia begins to market her crop, then Tennessee falls into line and finally the states north of the Ohio River.

Perhaps the one item that will make the watermelon crop a perennial question as time goes on will be the fact that it can be produced in any part of the state. The temptation will naturally be for everybody to plunge thoughtlessly into raising watermelons, and the natural result will be a glutted market. If the truckers in other lines follow the example of the citrus growers and organize for selling purposes this catastrophe may be avoided. At any rate, such a condition is a long time in the future. It will probably bring its cure as agriculture gets on a more business-like basis.

At present the watermelon trucker can sit down with a pencil and paper and almost figure out in advance what he will get for his season's work. Granted a sandy loam, constant sunshine, cultivation, and the vines do the rest, provided the grower has looked ahead and arranged for fortunate marketing. 
Solid train loads of melons, watermelons and canteloupes are shipped from Florida farms every day of the melon season. The buyers know where the melons are to be found. They are ready with check books. In one section of Lake County, within ten miles there were sixty watermelon buyers active in one season, and this little territory shipped five hundred and sixty-nine solid cars of melons. An average of $\$ 150$ a car is considered a fair price for melons, and this means a profit of this much or more per acre. When the vines are done producing and the last car has left the station the grower turns his ground under for another crop to be harvested in the fall.

Seventy thousand four hundred and seventyfour car loads of watermelons, and $254,52 \mathrm{e}$ crates of canteloupes have been reported out of Florida in a season, and the official figures are notably incomplete. 


\section{CHAPTER XV.}

\section{OTHER "BEST SELLERS."}

THe figures given herewith are gleaned from official sources. It is not mandatory that every grower or that every county report to headquarters, but the state officials, through county agents, have tried faithfully to get an adequate idea of what has been produced, as a basis on which to found the state agricultural reports. These reports are necessarily inadequate, but they form one of the most reliable sources from which one may judge of the varied field and garden products of the commonwealth. No figures are given on a number of important items, such as okra, cauliflower, asparagus, rutabagas, carrots, radishes, collards, turnips, brussels sprouts, parsnips, spinach, pumpkins, squash, butter beans, mustard, oats, rye, wheat, and many similar crops of importance, but a few figures on some of the better known producers and the locality that gives them most attention, are appended, as a sort of guide to the agricultural possibilities of the state.

Cotton. Twenty-four counties grew, in a recent year, 54,140 bales of ordinary cotton, valued at $\$ 3,000,000$. The same cotton today, with an advanc- 
ing market, would bring $\$ 6,000,000$. The high grade Sea Island cotton was raised in nineteen counties, with a reported production of 22,321 bales, valued at a little over twenty cents a pound. The same cotton later jumped to fifty cents a pound and the crop at this rate would have sold for $\$ 4,000,000$.

Peanuts. Thirty-eight counties reported 156,000 acres devoted to peanuts, with a crop of $1,854,235$ bushels, valued at $\$ 1.00$ to $\$ 1.50$ per bushel. Peanuts easily average $\$ 200$ per acre to the grower.

Hay. Scant attention, comparatively, has been given to hay and forage crops, yet 62,815 acres were reported in hay in a year. Much hay and feed had to be imported into Florida.

Sugar Cane. It is undoubtedly one of the coming money makers of the state. The Jesuit Fathers imported the seed cane from the West Indies in 1518. It had been brought over by Columbus on his second voyage in 1493. The methods for growing the crop and for extracting the juice are almost as primitive as they were when the Jesuits first introduced the cane into this country. One acre of a good crop of sugar cane, yielding about 400 gallons of sirup, will put more money into the farmer's pocket than fifteen acres of ten-cent cotton, and will require less work. Forty-eight counties "raised cane," and sold 94,800 barrels of cane sirup. Jackson County was in the lead, with 2,500 acres in cane. It can be profitably raised in every county in Florida. 
Sweet Potatoes. The Florida sweet potato, or yam, is the healthiest, best developed, most appetizing and satisfying article that ever went on the table. It is very generally cultivated. Reports show that fifty counties raised 2,776,000 bushels, worth from $\$ 1.00$ to $\$ 2.00$ per bushel. Sweet potatoes easily earn $\$ 150.00$ per acre profits, and from that up.

Irish Potatoes. While Irish potatoes find their greatest popularity in St. John's County, centering around Hastings, yet they are produced in thirty counties. St. John's County had twelve thousand acres in sweet potatoes. The state, as a whole, had 1,937,000 bushels valued at $\$ 2,500,000$ at the time. There have been periods since when this many Irish potatoes would have been worth a king's ransom. Irish potatoes will earn from $\$ 300.00$ to $\$ 500.00$ an acre.

Tobacco. Two counties, Gadsden and Pasco, have specialized somewhat in tobacco. Two methods were adopted, the open field and the covered, the tobacco raised in the shade bringing a much fancier price. Five hundred and thirty-nine acres of shaded tobacco in Gadsden County produced 1,600,000 pounds, and sold for nearly $\$ 800$,000.00. Eighty-eight acres of covered tobacco in Pasco County sold for the snug sum of $\$ 50,800.00$. Celery. Sanford and Manatee hold center of stage in the popular mind when celery is mentioned, because they have given great attention to 
this table delicacy, yet it is raised profitably in fifteen counties. Some of the waste ground just outside the city of Tampa is being devoted to celery, while the owners are waiting for the sale of lots, and fifty thousand crates are shipped from the suburbs in a year; 801,000 crates at an average price of $\$ 1.50$ per crate is the report of the state for a year.

Lettuce. This commands a ready market all through the year, but naturally brings fancier prices in mid-winter; 711,500 crates have been shipped, the prices running from $\$ 1.00$ to $\$ 2.00$ per crate.

Velvet Beans. There were 489,000 bushels of these produced in 43 counties and sold for $\$ 805,000.00$.

Peppers. Sixteen hundred acres of peppers were reported in the state with a production of 465,716 crates; they sold at an average of $\$ 1.50$ per crate. Many growers make from $\$ 750.00$ to $\$ 1$,000.00 an acre on peppers.

Tomatoes. Florida is getting almost as celebrated for its tomatoes as for its oranges, and soon the language of the publicist will change from the "golden gleam of the orange" to the "bloodred blush of the tomato," for while Florida shipped 9,000,000 crates of oranges and grape fruit, she shipped $3,619,000$ crates of tomatoes, valued at $\$ 5,500,000.00$. While they were raised in 24 counties, two counties were prize winners. Dade 
County had 9,500 acres of tomatoes and St. Lucie County devoted 5,000 acres to tomatoes. It is no uncommon thing for the grower to realize $\$ 1,000.00$ an acre on tomatoes.

Cabbage. They are raised profitably all over the state, but two counties, Alachua and Sumter, devoted the most space to cabbage; 545,330 crates were shipped at an average of $\$ 1.00$ per crate.

Cucumbers. They are popular in most of the state, but are produced heavily in Levy, Sumter, De Soto, Marion and Alachua Counties; 584,700 crates valued at half a million dollars have been shipped in a season.

Beans. Marion County, with 1,200 acres, led in the bean production; the state shipped 832,960 crates valued at $\$ 1,500,000.00$.

Egg Plant. Sixteen counties produced and reported on egg plant, shipping 585,000 crates at prices from $\$ 1.00$ to $\$ 2.00$.

Grapes. The largest yield was in St. John's County, though they are raised profitably in fortyfive counties. No consistent culture of grapes has been followed, and yet $1,385,000$ pounds were produced.

Pineapples. Only four counties, De Soto, Dade, Palm Beach and St. John's grew these extensively; 400,000 crates, valued at half a million dollars, have been shipped.

Pears. The common variety of pears yielded 28,425 barrels. The Advocada yielded 24,280 
crates, which sold for an average of $\$ 3.00$ per crate.

Other Items. Two counties, Dade and Palm Beach, shipped 65,000 bunches of bananas. Three counties shipped 29,000 crates of mangoes. Two counties, Dade and Palm Beach, shipped 4,000,000 cocoanuts. Bradford County, alone, shipped 2,217,000 quarts of strawberries in a season; 61,980 crates of guavas at a dollar per crate, were shipped in a year; 24,500 crates of figs, averaging $\$ 2.00$ per crate, went to the markets, and while the pecan business is really in its infancy in Florida, it is going to grow amazingly, for 20,000 bushels have been produced in forty counties, and extensive pecan culture is promised.

When the merchant or manufacturer figures, he sets aside a certain amount for the maintenance of himself and dependents. The figures given above on all items have not taken into account the amounts used at home, so they do not represent the total production; they do carry out, illustrate, amplify and bear out the contention that Florida is capable of producing a great many profitable crops; that these crops can be produced in almost any part of the state, that they can be marketed at the time of the year when nine-tenths of the states of the Union are held in the grip of winter, and hence, can be sold at fancy prices.

They dispel the idea of the ignorant and uninformed that Florida is a great jungle, a pathless 
wilderness, a hopeless swamp, a vitreous sand pile, a rendezvous only for snakes and alligators, and they dispel the commonly held theory prevalent for many years that oranges were the one possible crop that could be profitably raised.

Intensive cultivation of the soil in any one of 50 counties, together with sensible rotation, reasonable fertilization, and an eye on the market, will bring handsomer returns than stocks, bonds, banks, investments, securities, or any of the commonly accepted forms of investing money.

Another Little Item. And not so small after all; so big, in fact, that it is hard to grasp. Even in the imperfect list of products mentioned above as being shipped in the course of a year, the item of crates and cartons and barrels for shipping purposes is one that makes a great industry in itself. It is fortunate that Florida has such an abundance of wood, for its products are largely shipped in crates and these crates have to be made. The trees have to be found, the lumber cut, and men employed to put the crates together. It would take $24,581,000$ crates, cartons and barrels to hold the shipments mentioned above. It requires an army of men to make these shipping conveniences. If you ever have a desire to see a human machine work with electric-like rapidity, go some day to an orange packing house and see the men literally throw together the orange crates; they do piece work entirely, and no other form of manual labor is ever performed with such lightning rapidity. 


\section{CHAPTER XVI.}

\section{STOCK RAISING.}

HERE, again, opinions conflict. A couple of years ago the agricultural department reported the following on hand: Horses, 55,000; mules, 37,000; oxen, 8,200 ; native stock cattle, 855,900 ; thoroughbred cattle, 20,208; milch cows, 41,680; hogs, 662 ,370 ; sheep, 120,200; goats, 49,270; chickens, $3,844,776$.

Florida cattle are pretty generally judged by the scrawny little specimens that one sees along the railroads, browsing on tufts of grass, chewing at the bark of trees, and in other ways, trying to eke out a living. If there is one card in the deck that Florida has overlooked shamelessly, it has been the matter of its stock. The result has been that great train loads of Armour's and other meats have been shipped in from the West, and these have helped in destroying a domestic industry of much promise.

For a long time, it was generally thought that the climate of Florida was not adapted to the growth of fine cattle. The real truth of the matter is, that fine cattle have never had a chance. The fallacy as to climate has been refuted times without number. Florida stock has suffered severely 
from the prevalence of the "cattle tick," the same little pestilence that nearly put Texas cattle out of business a few years ago; but Florida citizens and practical stock raisers have taken hold of the tick proposition in such a thoroughly skillful manner that the "cattle tick" is not thriving as it formerly did.

There is no reason under the sun why Florida should not rank with Texas in the raising of fine stock. The trouble has been with the stock raisers and not with the stock. On account of the even temperature, and the great boundaries of unused land, $90 \%$ of Florida cattle have had to shift for themselves. They were simply turned out, were not fed, nor watered, nor salted. The breeds were not improved. No encouragement whatever was given to the ambitious young steer to become large and juicy, for, throughout the whole year he had to browse around on whatever happened to be loose in the way of food, without any encouragement from the barnyard.

Another impediment was the lack of hay and other rough feed for stock. Until the last five or six years a silo was unknown in the entire state. Attempts were made to raise hay, but only in a spasmodic way, and without consistent study of the soil and the crop desired. A few years ago some experiments were made in Natal hay, this crop having been very successful in Natal, South Africa, on a similar soil to that of Florida, and 
now Natal hay is fast becoming one of the staple crops of the state. It can be raised in any county and is peculiarly fitted to the sandy soil. In this regard, it is unlike alfalfa. Alfalfa does not thrive in this texture of soil; Natal hay is adapted to it. A few years ago, great quantities of hay were regularly shipped from states further north right into the agricultural state of Florida. This was naturally costly, and it put a ban on the development of stock raising. The prediction is freely made that Natal hay will relieve this situation in a short time; that it will become generally known throughout the state; and it is such a succulent and nutritious grass and is grown so readily that there is reason to believe that Florida will be exporting to other states large quantities of this new grass. It sells for from $\$ 20.00$ to $\$ 25.00$ per ton, and cuts from two to four crops a year. After the first sowing it grows spontaneously for a number of seasons. If it proves as successful as its adherents claim, the stock situation in Florida ought to be revolutionized within the mext ten years.

The foregoing is not intended to convey the idea that no attention has been paid to stock raising, for there are large ranches in various parts of the state, some of them having as high as 25,000 head of cattle, and an appreciable lot of Florida stock has been shipped to the northern markets. It is claimed that the native meat is even more pleasing 
than that shipped in from the West, but, to an observer who goes along the railroad lines and sees the thin-visaged, long-horned cattle browsing on the thin grass, the prospect for cattle is not promising. The three things: Lack of consistent care of the stock already in the state, the lack of satisfactory hay produced locally in large quantities, and the failure to bring into the state for breeding purposes a better class of stock has accounted for the situation as it now exists. That it will be improved rapidly, and that the Florida of tomorrow is to be one of the leading cattle raising states in the nation within a decade is easily seen. The authorities of the state are bending every effort to improve the situation, and they are bringing to their assistance all the latest developments of science, are establishing experiment farms and stations, are bettering the breeds, and are flooding the state with literature on the subject.

When it comes to hogs, one always thinks of the razor back, and naturally adverts to Bill Nye's idea of the razor back as being "built for speed" entirely. They are speedy, they are certainly thin, and they do not have the appearance of being fit to eat; but this is also on account of the fact that in ninety cases out of a hundred the young porker has a hole punched in his ear, for identification purposes, and is turned loose in the wilds to work out his own salvation. He has no help or assistance from his owners. We are persuaded 
that the same class of stock would be resultant, if the same methods were pursued in Kentucky or Kansas. There is no inherent reason why the breed of hogs should not be improved. The weather conditions and climate are favorable and there is ample room and plenty of water. If Florida farmers and stock raisers take hold of the stock proposition and pursue it as has been done in other states, it will be one of the greatest sources of revenue that can be found.

Another idea that has been prevalent, and which has been disproved is that chickens would not thrive in Florida. The writer is not a poultry authority, but, in his travels through various states he has never seen a more healthy, thrifty lot of chickens than the fifteen hundred or more which he saw in one poultry yard at Clermont a year or so since. They were White Leghorns of the highest type. The owner was a practical man, and there was such a demand for the eggs that he had them sold to regular customers months ahead at a high price, and these were shipped to the big hotels on the East Coast. This one instance, if there were not thousands of others, would disprove the popular fallacy that chickens were not adapted to climatic and other conditions in Florida. As a matter of fact, on account of the lightness of the soil, there are fewer of the ordinary diseases and perils that thin out the chicken tribe in Florida than any place else in the country, and the same amount of 
care devoted to chickens that is given them in the older states would pay large dividends.

We doubt whether horses will ever be much of a factor in Florida. They are getting to be a negligible factor, except for plowing and some of the rougher kinds of farm work. The automobile has put the horse out of business. Of course there are horses. Some few years ago the benevolent purpose of the Federal government was to supply a large number of our fellow citizens with "forty acres and mule." Many of them have their mule yet. The horse and the mule have not, and we believe never will have a sufficient amount of attention in this state to make it compete with Kentucky. The automobile, the truck, and the tractor will fill the bill for the future. 


\section{CHAPTER XVII.}

THE EVERGLADES.

You cannot side-step them, nor skip them, nor overlook them, nor forget them, nor "soft pedal" around the subject, for wherever Florida is discussed, there are those Everglades bobbing up staring you right square in the face, demanding settlement.

What about them?

In the first place, let us admit that they have been discovered, that they are there and will have to be dealt with.

The Everglades lay below the 27th parallel, have a width of about 45 miles, are about 100 miles long, and, together with an accompanying area that also needs drainage, cover about 4,300,000 acres. The surface of the Glades is 21 feet above sea level in some places, and slopes gently toward the south. Contrary to the usual conception, engineers who have been all over the territory say that the Glades are in no way a swamp; they present the appearance of a broad, level, grass-covered prairie; there are practically no trees. Clumps of small bushes are found near the eastern and southern edges. They are covered almost uniformly with a growth of saw grass. In the campaign of 1905 the 
successful candidate for governor of Florida was elected on a platform pledged to the drainage of the Everglades. That was over ten years ago and the Everglades are still with us. In the meantime, a great amount of reclamation work has been done. Over 300 miles of canals are now open. The canals now contracted for or under construction, emptying into the sea from the Everglades, if placed side by side, would be equivalent to a river 500 feet wide and ten feet deep.

Similar projects have been carried on in many countries, including the lowlands of Louisiana, the inundated territories of Holland, and the Fens of eastern England; but, in the last generation, no greater engineering feat has been undertaken, outside the digging of the Panama Canal.

Unfortunately, the Everglades got into politics. Campaigns have been lost in a most unscientific way, the fight hinging on the practicability of their drainage. The fight has been carried into the higher courts of science. Engineers and experts of the Federal government have been called in and their opinion sought. Then an appeal has been taken to the Supreme Court of scientific opinion in centers of learning throughout the world, and majority and minority opinions have been handed down. In the meantime, they kept on digging canals and draining the Everglades.

One side claimed that the Everglades could not be drained, and if drained, they would be 
worth nothing; the other side put on its witnesses and proved that the Everglades are some twenty feet higher than the surrounding ocean and gulf and cited the axiom that water will run down hill. The preponderance of testimony on the part of scientists and engineers is that they can be successfully drained.

There is no question but that the first thought of their reclamation proceeded in large measure from corporations, companies and individuals who had staked out claims at a very small price, and who with the desire to make money, projected the idea that the draining of the Everglades would leave a fabulously rich territory for cultivation.

But the State of Florida went into the proposition on a business basis. While the question has been the football of legislatures and the bone of contention of scientists and engineers, the work has gone steadily on. The only people who have remained serene throughout this period have been the Seminole Indians. The last of this imperious race has been shoved by civilization from place to place and finally have made their last stand on the edge of the Glades. There they maintain their original traditions, their habits, their customs, their speech, and they have found an easy livelihood in fishing and hunting, and in the simpler pursuits of agriculture. If the Everglades prove the rich prize that is claimed, we presume the next 
move will be to shove the Seminoles over on the Dry Tortugas.

Efforts so far made have seemed to prove that the muck that covers this great area is rich and responsive. Vegetables of enormous size have been raised. In a measure, the judgment of the scientists favoring drainage has been correct. It cannot be fully declared that all of the territory so drained will be practicable for agriculture, but the presumption is in favor of this argument. It has not absolutely been proven that the drainage of the whole territory is possible because the levels are not well enough known, but the preponderance of evidence is in favor of a fairly complete drainage, and also that a rich muck adapted to vegetables over much of this area will be secured.

Now, as to the practical features of this great development as it relates to the grower, the average farmer and the investor. Because the Seminoles live on the edge of the Everglades is not to be taken as the best evidence that other people can thrive there. Even with drainage, the territory is low, the saw grass is high, the mosquitoes physically gigantic in size, the air laden with noxious vapors at times, the atmosphere heavy and inert, and there is everything enervating calculated to depress and not have that exhilarating influence that one feels in a higher altitude, or in a Northern climate. Health and living conditions are of paramount importance. It is impossible to conceive 
that this will ever be satisfactory in this part of Florida.

Those who have so vehemently argued that the Everglades cannot be drained are perhaps wrong. Those who have maintained that this will make one of the garden spots of the universe, inhabited by a thrifty and satisfied people, are equally in error. The Everglades is no place for the independent man, the man with limited means, the man with a family to raise, with children to school and dependent on his own exertions for a living. This country will have to have millions more people before there could be serious reason for the ordinary man detaching himself from society, pioneering in a newly made empire, abandoning the habits and pursuits of regular civilized life and attempting to make a home place where living conditions must necessarily be a question for a long time, and where health and comfort are questionable.

It is fortunate that the government stepped in and put a quietus on what was popularly known as the sale of Florida lands "by the quart." Figures ofttimes tell a fascinating story, and human nature is forever prone to want to send its money away off somewhere, to chase down the channels of chance, to pursue the purely speculative rather than to buy the known and knowable. Many people were lured by the amazing statistics of what could be grown, and, that a remarkable vegetation can be produced stands today without challenge, 
but it is one thing to know that a territory will respond to culture by bumper crops and quite another to make that country home.

We hold that the old world has traveled along far enough now to rid itself of the necessity of great pioneering, such as was necessary when countries were new and when the pathways through the wilderness had to be trod by hardy feet. At that time it was all right for the hero to go it alone, to leave his wife and children to wait through the weary months and sometimes through the years for his return.

But we do not need so much of that sort of hardy citizenship now. We like the idea of seeing the school house and the church and the social center follow the man with the title bond to the new claim; to see the little cottage, the wife, the mother, the children, the county fair, the friendly games, all these indicative of a community that is making its home some place, and not merely a bunch of men who are camping out on a claim temporarily. If the Everglades are drained and thrown open to cultivation, they will be cultivated. There are men who will volunteer for any pioneer work, whether to penetrate the ice fields beyond Nome or the rice fields of the farther South, but it will not interest the average, every-day, hard-working, home-loving man who expects to go to Florida to make his home. Time will come when every acre of this old country will be utilized to maintain the 
millions who have flocked to the Stars and Stripes, but let those fellows twenty-five, fifty or a hundred years from now fight the battles, that you and I do not need to bother our heads about. 


\section{CHAPTER XVIII.}

\section{"TEN ACRES AND INDEPENDENCE."}

THIs has been the rallying cry, the clarion call of the publicist, the promoter, the colonist in Texas, Missouri, Mississippi, Louisiana, Florida and other southern states for a generation.

It sounds good.

It has been heard in the far-away Rockies, in the pine forests of the Great Lakes, in the Virginias, along the Mississippi, down the St. Lawrence and across in the provinces of His Majesty, George. From the field, the office, the mill, the mine, they have lent their ears to the far-off sound of independence, and have rallied to the call.

And while it has truthfully been charged that men and groups of men have in times past, through misrepresentation and fraud and subtle influences, conspired to cause unsuspecting purchasers to buy what they had for sale, and while these same influences have had a damaging effect on a territory that was marked by them as their prey, yet, let us not generalize too widely and assume that all of the promotion of Florida has been with sinister purpose, nor even that a majority of colonization schemes were founded on fraud. This 
is not the case. Indeed, a very small percentage of the publicity work done to acquaint people with the advantages of this southern empire has been intentionally deceptive and dishonest. The most of it was honest, fair, plain, sincere, and based on actual conditions that could not well be over-pictured.

Honest men, and strong organizations have exploited desirable parts of Florida, and have brought to the state much of its best citizenship and its wealth. They have used this rallying ery "Ten Acres and Independence" honestly and fairly and have stood ready to prove that it was not a poet's dream.

It sounds good. Like all fallacies, it is based on truth, and has lured the hard-earned savings from the pockets of many a man of meagre means. It has lined the silken pockets of many a skin-flint.

The misleading truth is that ten acres, consistently cultivated in Florida, has in numberless instances, brought independence, and sometimes affluence, to the owner. It might almost be said that ten acres, consistently cultivated and sensibly marketed in practically any part of Florida, will bring a competence or at any rate, a good living. Hence it is that the slogan is all the harder to refute, because it is based on tenable grounds. There is not the slightest difficulty in establishing by innumerable, competent witnesses, that ten acres, or even five acres, with the right cultivation, has 
brought forth abundantly and made its owners independent citizens.

The case is just as simple as can be stated. Take an ordinary ten-acre grape fruit grove that has been set out six or eight years and has had good care. There is no reason at all why such a grove should not bring the owner, with an average market, at least $\$ 400.00$ per acre, which would mean $\$ 4,000.00$ a year. Many groves bring more. Many groves bring less. This is not an unusual average. And it is easy enough to maintain that to the average man who has not been in a high-salaried position, nor in a great money-making business, that $\$ 4,000.00$ a year is a very snug sum, and puts a man safely on "easy street." It might not seem like affluence to Carnegie or Rockefeller, but it would look mighty good to most men.

Why not, therefore, join lustily in the cry and let it be known from Dan even to Beersheba that in the glorious State of Florida, where the birds sing, and the flowers bloom all the year round, that life flows on in endless song, that joy is unconfined, and that any man can go down, buy ten acres and be independent.

Why not reach the languishing millions in our congested centers of population, waiting for an opportunity like this? Are there not millions of hungry children, herded in the tenements of our great cities, whose health would be built up, whose lives would remain joyous, who would see a gleam 
of hope in the East, if their parents were to take them from the grewsome surroundings under which they exist, and place them in God's sunlight, on ten acres in Florida? Are there not weary workers in forges, in mills, and shops, and stuffy offices, whose health demands that they get out into the open, and who could leave these healthwrecking, nerve-racking surroundings, and become new men on ten acres in Florida? Are there not thousands of discontented women, widows, spinsters, teachers, seamsters, stenographers who could easily look after the cultivation of a tract as small as that named, and from it bring forth independence.

Let us grant again that it is from among these very people, many of them, that come the bestillustrations that ten acres and independence can be found in Florida, but is the old case of "the exception proving the rule." If the mill worker in the Pittsburgh district who leaves his machine or his forge, takes with him his little family and settles on ten acres in Florida, were a farmer, naturally had the soil instinct, and would acquaint himself with local conditions, and fortify himself against failure, with steady courage, energy and good headwork, then there is no question but that ten acres in almost any part of the state would bring him returns better than he ever received in his life before. As a matter of fact, if he cultivated his ten acres intensively, didn't depend too much on 
hired hands, spent a very small portion of his time at the village store discussing affairs of the nation, rotated his crops and watched the market, ten acres is about all that he could take care of.

The farmer in the central states, with some help tills fifty or a hundred and fifty acres, but the gardener in Florida has all that he can attend to if he looks after twenty acres or ten acres, and there are times when five acres will keep a man busy.

By way of illustration: On a train coming out of a little city in Osceola County a year or so since, a young man sat down by the writer, and while well dressed, his hands were badly stained. He excused himself, saying that he had been working very hard and could not get the stain off. We asked further about his work and he said that he had just marketed his lettuce-most of it. Naturally one inquiry followed another, and he said that he had five acres in lettuce. We sought to find out about what the five acres would produce and found him modest-that is, he had not much of the braggadocio that goes with success. $\mathrm{He}$ said that he had marketed, so far, five thousand dollars' worth of lettuce, and that he thought he had a couple of thousand dollars' worth more which he would market in the next two or three weeks. This was a bona fide case, for inquiry in town developed that not only this man, but many others, had been equally successful with their own crops. 
It is cases like this which enable the promoter to herald the cry of independence, because, under conditions like this, ten acres, if cultivated, will bring rich returns, and there lies the principal fault.

If every automobile manufacturer succeeded like Henry Ford then we would all be wanting to go into the business; but they do not all succeed, though they may make as good a machine as that put out by the Ford works. If every oil venture was a success then we would all be John D. Rockefellers; but the financial cemeteries of the country are absolutely filled to overflowing with oil operators and prospectors who failed, while John D. Rockefeller succeeded.

The dangerous feature of letting the slogan be distributed broadcast is that it will reach the eye of the overworked miner, the rheumatic carpenter, the dyspeptic clerk, the sick mill man, and that these, without counting the cost, figure that all that is necessary for them to do is simply to send their money down, secure the title to the ground, and then move on to their little principality and begin living high; and they overlook the fact that this cannot be done in any other part of the known world-that if they buy a farm in Indiana or New York they have to cultivate it with a great deal of care in order to get returns. They lose sight of the fact that if they cease working for a minute in any ordinary avocation that just at that par- 
ticular minute the pay stops; but they are influenced by the glamour that accompanies much of Florida publicity and jump at the conclusion that here at last in this green land, just this side of the "Pearly Gates," they can quit work and yet live. It is unfortunate. Some have found the fallacy before they moved; others have faced it when they reached their land and saw nothing but work was their salvation; and the country would have been vastly better off, Florida would have been generations ahead in improvement, and many a poor man would have been satisfied instead of being a malcontent if he could have borne in mind the timeworn edict that man must eat his bread in the sweat of his face.

The same class of demagogic traffickers in another line of business, steamboat agents, is responsible in a large measure for the great hordes of ne'er-do-wells that throng our shores from European and Asiatic countries, telling the oppressed people that in America everything is free, that work is easy and wages high, and that all they have to do is to rake up enough to pay steamboat fare to America, and there they will be rich. These people wake up on Ellis Island and find themselves out of money-with no work, unacquainted with the language, with no knowledge of the country, and it is little wonder that many of them retain the anarchistic seed that has been planted on the other side, and that it takes generations to prove 
that we have everything over here that mortal man could wish, but that it is not free, and that man gets his day's wages after his day's work is done.

The question arises, Should the poor man go to Florida? Well, yes, but the question ought to have a large capital limitation to it. The man without any money had better stay right where he is, particularly if he is among friends, because Florida is not the place for him. This is another reckless, extravagant use of words that has prevailed in much of the advertising literature. There has been a sinister idea expressed, or at least, implied, that this is a poor man's paradise, that it took no money, that it took little work, and there is a very well defined notion that lots of people who have migrated to Florida have done so with the idea of divesting themselves of all efforts. Such people have often ridden back on freight trainsand they ought to do so, unless they are made to walk, for there ought to be no part of the world where a man can feel he is entitled to his daily bread without working for it.

Florida is no place for a poor man, that is, for a man without any money. It is the place for a man in moderate circumstances, the one who has a little money, enough to take care of himself until his ground begins to produce; but if he goes to Florida flat broke he will become a public charge, just as he would in any state in the Union unless he fortunately finds somebody who can give him 
work. It is not to be concluded that Florida appeals to the rich; for while there are many well-todo people migrating to that state, some have winter quarters and live there the year around, yet Florida's strongest appeal is to the man of moderate means, and that appeal is to the very mill men and office men, and others mentioned just above. These men can do well in Florida. They can get away from conditions that are undermining their health, they can get out where competition is not so severe, they can raise their families under the most fortunate circumstances, but they must not attempt to realize this dream of ten acres and independence without either money or work, and they should have some of both. And it is only fair to say that no part of the Union offers greater inducements to the man who is willing to work, and who has a little bit of cash to maintain himself while his crops are coming on than Florida; and it would be a heaven-sent blessing if these hands of the sweat shop, toilers in our great industrial centers would throw down their tools, take their savings with them and go to Florida and begin cultivating the soil; and men like this with the spirit of the hardy pioneers, and with one-tenth of the work that these pioneers put into the soil, will realize the dream of independence that comes from the proper cultivation of a small piece of ground under such wonderful climatic conditions. 


\section{CHAPTER XIX.}

THE AUTOMOBILIST'S DREAM.

During the twenty years of the popular life of the automobile, since it came to be the vehicle of the man of moderate means, the country has made 150 years' progress in the building of good roads.

Florida is not only a state "of magnificent distances" but its topography and structure are such that roads are easily built. A road that would cost $\$ 20,000$ per mile in West Virginia could be built for $\$ 2,000$ a mile in Florida. There are practically no hills, few rivers to cross, no sticky clay, and it is a question of only a few years until Florida will be honeycombed with hard roads. They have caught the step with the foremost states in the spirit of road-building and are many paces ahead of three-fourths of the states in the Union in this regard.

The old Florida road was a fright. It came by chance, was laid out by caprice, and existed by necessity. It was nothing more or less than two gutters cut in the sand, and usually cut in the most erratic manner, indicating that the original pedestrian or teamster who trod out the path was on the border of delirium tremens. In later years, 
when the automobilist came along, if he followed the zig zag course, he could keep going, provided his wheels had the same tread as the wagon which went before him, but if he once got out of the sandruts it generally took a mule team to get him back into one.

This was the Florida road of yesterday. It was followed by the sawdust road. It is surprising what an improvement a six-inch layer of ordinary sawdust makes on a Florida sand road, but there is just all the difference in the world between the old sand road and what Billy Sunday might term the "sawdust trail." The sawdust road was followed by the pine cone road. Outside of starting fires in the kitchen stoves, this was the only use of a practical nature, to which the pine cone was ever diverted. But it made a better road than the old sand highway.

The Florida road of tomorrow will be an idealist's dream of easy travel. Talk about energy and faith, and nerve, and grasp of the future, those people in Florida have it. They have seen a vision of a new state. They have caught the spirit of progress, and it doesn't make any difference how heavily burdened the county is, how seemingly adverse the crop situation, how poor the prospects, or how remote the county is from the great centers, those fellows that make up the bone and sinew, the brain and brawn of the Florida counties, are right in the forefront of the 
ranks that are clamoring for hard roads. Hillsboro county is, of course, one of the more densely populated, and it is a pace setter. Duval county is not far behind. Call the roll of the counties and almost everyone will answer "yes" on the question of good road building. Hillsboro county, several years ago, voted a million dollars for brick county road paving. Orange county has built its county roads largely of brick. For years, the automobilist has been skimming along the East Coast on delightful shell roads.

The ordinary hard road, or clay road, is a simple structure in Florida because the materials are omnipresent. $\mathrm{Be}$ it known that throughout the state, just underneath the covering of sand varying from 18 inches to five feet, there is a layer of clay, sometimes known as hard pan. This clay mixed with the common sand, makes a very passable, hard-surfaced road, and many hundreds of miles of this road have been built in all parts of the state; but progress is progress and the best is none too good; so the advanced thinkers and shrewd business men of the state have even gotten beyond the ordinary clay road. It is being superseded now by the sand oil road, the macadam road, the asphalt road, and the brick paved highway. Compared with her ability and with the territory they have to cover, Florida is spending more money on permanent highways than any state in the Union. 
The Dixie Highway is the supreme effort at an alignment of all the various highways into a given course. It is rapidly tunneling its way through the solid South. It is making strides through Florida and will finally reach its uttermost Southern cities. Someone has said that he never struck a Southern city where he was not met at the city gates, given the glad hand, and informed at once that the city he was in had the supreme distinction of being on the celebrated Dixie Highway. This is putting it jocosely, but it does illustrate the avidity with which the Southern part of our republic has taken to the idea of good roads.

Let's see how this idea begins to form, and take on consistence, and how it begins to commercialize. Let's reduce it to the least common denominator and see whether it will show on the cash register, and in the bank account of the Floridian.

In the first place, it gives a rapid, economical, and reliable way of getting roads to and from the market. It has taken a volley of logic, and argument, and persuasion to punch this idea into the heads of farmers in some parts of the country but it is gradually going through. The Florida grower has not been hard to convince.

But there is another item worth figuring. Florida people are entertainers. Their country abounds in hotels. They send out invitations broadcast for the rest of the world to come and see them, particularly in the winter season. Large numbers 
accept the invitation. If the Dixie Highway, an all the year dependable, easy graded, hard surfaced road was completed through to Jacksonville on to Miami, down to Tampa and Fort Myers, out to Tallahassee, and Pensacola, and to the other traveled sections of the State, there would be during this next winter, no less than 100,000 automobiles, Fords, and otherwise, loaded with excursionists bound for Florida, and they would go through the state, drinking in its scenery, visiting its resorts, patronizing its hotels and stores, attending its playhouses, buying its fancy fruits and dropping coins at every turn of the road aside from amounts deposited with Rockefeller for gasoline and every cash register in the State would feel the impulse of a new life as the result of this visitation. More than that, these people would be repaid a hundredfold for the outdoor journey and would go back to their homes renewed and invigorated.

Good roads pay. They pay the builder and the traveler. If Florida, with other supreme vantage points, was still fenced in with ancient sand roads, it would be a hopeless case. 


\section{CHAPTER XX.}

\section{THE BOOSTER SPIRIT.}

Aus the world loves a lover, and all the world admires a booster. The booster is a distinctly American species; he may have imitators in some of the wornout monarchies on the other side, but his characteristics are distinctly American.

Florida is the native home, the birthplace, the congenial atmosphere, the permanent abiding place of the booster.

It is the proper spirit, and it pays. When we drop into a little town and talk to some sourgrained, cloudy-visaged dyspeptic, fault-finding fossil who begins by criticizing everything about the town, apologizing for this and that, and telling how much better some other place is, we set it down that that fellow ought to move on to some place that he does like, and usually a good, wellkept cemetery is the best place for him. Our cemeteries are just simply yawning for that sort of people, and nobody ever misses them.

You do not find many of this class in Florida; the fellow who dropped in from Minneapolis day before yesterday, run around the town a few hours, got acquainted with a few of the leading people, and secured a regular boarding place, bobs 
up at the station the next morning a full-fledged member of the reception committee, grabs the first man who gets off by the hand and begins telling him what a good town we have, what a splendid school system, how large the groves are, what big shipments of vegetables were made last week, about the new waterworks and the electric light plant, and the new school building. The spirit is contagious; the man just off the train catches it and begins to like everything he sees. It is this spirit that builds up towns and cities, and communities, and states.

Every little city in Florida has its Board of Trade, its Chamber of Commerce, or some such organization with a "pull together" spirit, and it is amazing what attractive circulars and folders and booklets can be gotten out regarding the most unpretentious municipality. They do not prevaricate. They merely see to it that none of that fine flavor that should accompany the truth is lost. They catalogue every strong point, and overlook the weak ones, if there be any.

It is a splendid spirit of hopeful communitybuilding and state enhancement that prevails in Florida. It is the spirit that would make anything succeed. It is a good atmosphere to move into. It is this encouraging attitude, this royal welcome to the newcomer that has hit the sunny side of many a man who went to Florida simply to stay a week or two weeks, but which caused 
him to buy property, establish a home, get into business, become a part of the boosters' organization, and to immediately engage in writing letters back home to the fellows he knew, telling them that you couldn't hire him to live any place else in the world.

The good old Florida "Cracker" is a solid, substantial, reliable citizen. He is not given to exuberance, or boosting, naturally. But so many people from so many states have adopted Florida as their home, and have become the "Old Timers" that you cannot tell now who-is-who or where he came from, and they all join heartily in the chorus.

\section{"BELOW THE FROST LINE."}

Newspaper offices keep this line in type, as a necessary part of the ad of every real estate man and community. It is one of those mystic things that you read about and never quite see, like the bread line in the big cities and the life line that they sing about throwing out at the revival meetings. A hundred places in the state appear cheerfully and confidently before the public in the unique announcement that they are "below the frost line." They are not. The only reliable frost line that can be depended on is the equator.

Of course whimsical reports that skaters have broken through the ice at Daytona and been drowned, and other vagaries of the funny men are to be taken for what they are worth. 
There is no frost line in Florida, no place that is immune from an occasional nip of this dread visitor. Communities have been free for years and about the time they began to get puffed up and to feel that they were on the safe side, a little frost has come along some night and cut down a few acres of tomatoes or peas and taken the wind out of their sails.

It must have been this feeling of security which preceded the freeze that came in February, 1895. Florida at that time was devoted to one croporanges. Its whole fortune was staked on the one bet. It lost. The freeze came. Hundreds of grove owners were wrecked. Many of them gave up hope and turned their steps north. It was a dismal scene. It showed that even a freeze is not absolutely impossible in Florida. Nor is an earthquake impossible in California, nor a disastrous tidal wave impossible at Galveston. Calamities know no bounds. If the world quit when a calamity overtakes a given section there would be lots of abandoned sections of the land. The Mississippi valley would be a manless desert. The Ohio valley would be deserted. The fields of Kansas and Nebraska would be turned over to the coyote. There are no sure things when you deal with nature.

It is said that the morning after the freeze, when the disheartened orchardists gathered themselves around their little fires, and looked on the 
desolation that the ice had wrought, they were hopeless and despondent. They saw no hope of rebuilding their fortunes. It would take at least five years to make producing groves again. What were they to do for a livelihood in the meantime? Some of them remembered that they had packages of seeds in their trunks and bureau drawers, brought with them or sent to them by generously disposed congressmen. They had been confining their attention to the one crop. They had taken it for granted that the soil was adapted to nothing else. But necessity overlooks tradition. They got out their seeds. The mocking sun was coming down with its old time fervor. They scratched out patches here and there and sprinkled a little fertilizer around. In six weeks some of them had lettuce and beans and other garden products. The freeze had brought its lesson. It had turned Florida from dependence on one crop to a variety and from that day on the Florida gardener has kept experimenting until he has arrived at this fortunate situation. If a freeze should visit the state again, and this is only the remotest possibilityit might take one crop, or all that was in the ground at the time, but it would not be over eight weeks until Florida would bob up serenely and have another harvest ready for the markets.

There is no section of the state absolutely free from the chance of a frost. They have them at Miami, hundreds of miles south of Jacksonville, 
They have them at Sarasota, far down the gulf. They are not frequent nor do they do much damage, but they have them. It is only once in a long while that vegetation suffers from the chill. The tomatoes occasionally go down. The tenderer and more humid of the vegetables may wilt, but it has been many a long year since the oranges were affected adversely by a cool spell.

In the higher land, on the ridge that runs through Polk, Orange, Lake, and other counties, and especially where there are large fresh water lakes, the sting of the frost is tempered to such an extent that its effect is negligible, but, still, there is now and then a little cold spell, when the thermometer wobbles down around the 35 mark Fahrenheit, and the trucker looks and feels uneasy. Whenever a big blizzard is reported as holding the north in its grasp, and the newspapers bring reports of below zero throughout the land, it may be counted that the scattered fringe of the storm, the wake, the aftermath, will touch even Florida, and an extra wrap will not be out of place.

"Below the Frost Line" is a misnomer. "They ain't any sich animal." The best engineer on earth cannot traverse the state with his instruments and lay off any line that will approximate the statement. The frost, in a slight measure, will hit this locality or that once in a while, and will chill the crops. It does not frequently do damage 
that amounts to anything. In the southern part of the state it is infrequent and practically harmless. In the northern sections it is rare, but there is no place that can truthfully say it has not seen a white covering on the roofs and the ground once in a while.

It is not a menace. It does little damage. It is hardly a factor that the prospective investor needs to deal with in his calculations, but there is no use kidding ourselves into the notion that frost does not exist.

THE OTHER EXTREME.

And, on the other hand, while weather is the topic, the old supposition that a man would burn up if he braved a summer in Florida has been set aside along with all the other exploded theories that have been laid on the shelf by investigation.

Since Tampa is about the geographical center of the state, or at least not far south of that point, let us compare Tampa heat with that of some other places. When the weather bureau began publishing daily statements of the weather throughout the country, and a chance for comparison was given, it was at last realized that the temperature of Florida never reached the excessive figures that were frequently shown in many northern cities. Take Los Angeles, on the west coast, for purposes of comparison. Los Angeles is a city of half a million people, built upon climate as 
its chief asset. Yet the official weather bureau records show that during the year, when the heat in that city reached the excessive figure of 109 degrees, and the lowest point reached during the winter was 29 degrees, a range of 80 degrees, the highest point recorded in Tampa was 94 degrees and the lowest point 32 , a range of 62 degrees. The highest point reached in Tampa since the records have been kept, covering many years, is 96 degrees. Many cities in the farther north report the thermometer at times as high as 100 and some even higher, and these cities report numerous instances of sunstroke and heat prostrations, while such a thing is not known in Florida.

Florida's hottest month is usually April. Sometimes March is continuously very warm. In midsummer the excessive heat is broken by the daily rains. The nights throughout the year are cool. There is a good breeze blowing from ocean and gulf and Fort Myers is a cooler spot than New York or Chicago in August. The heat of the day is intense, but the shade is also vivid. Those who have lived for years in the central states and then taken up their residence in Florida have uniformly reported that, so far as the heat was concerned, they were much more comfortable in the latter state during the summer hot spell. 


\section{CHAPTER XXI.}

\section{FLORIDA'S CALL.}

IT comes to all the people some of the time, and to some of the people all the time. "For his gayer hours she has a smile and gladness and beauty, and she glides into his darker musings with a healing, an unknown sympathy which steals away their sharpness ere he is aware." It has a peculiarly subtle charm from many standpoints for many people.

It is a varying call, a strong, persuasive, compelling call, that is answered generously, at least in the winter months. This beckoning hand is strongest to the nomad, the wanderer, the foot loose, who tire of the monotonous, dry scenes of routine life and who feel the wanderlust in their bones. They want to get away, to go some place, to experience a change of scene. The West Coast, the Land of the Setting Sun, has its myriad attractions, but California is three thousand miles away, while Florida is only 24 hours from Cincinnati, 30 hours from Cleveland, 30 from Chicago, 30 from Philadelphia. It is easy to take the trip, so, when the first flurries of snow come, and the chilly blasts begin to creep out of the north, the nomad begins to pack up and to look over time- 
tables and hotel rates in the South. In a very short time he is on the wing, and he lights at a gay hotel, or by the side of a little lake, or on one of the keys along the coast, and nestles down to enjoy the winter.

What a panorama opens up to the visitor. What numberless places taunt him with their peculiar attractions. How he often wanders from one to the other, flitting about as he follows the impulse of the hour.

He can wander around the quaint little thoroughfares of old St. Augustine, explore the fortress, the moat, the old mission, the slave market, hear the bands in the park, sail on the Indian River, mingle with the throngs that wander around the princely gardens of the Ponce de Leon or the Alcazar, or he can rest on the cliffs and watch the surges of old ocean roll in at Sea Breeze, or enjoy the moonlight from the deck of the steamer as she winds her way slowly up the majestic St. Johns, or can creep along the jungle course of the weird and mystic Oklawaha up to the famous Silver Spring from which the river has its source, or can play golf at Bellair on the finest course in the country, or hunt ducks up the Caloosahatchie, or join the millionaires in their gay pastimes on the broad verandas and in the spacious parlors of the Royal Poinciana or the Breakers or the Tampa Bay. He can hunt out some little hamlet in the quiet of the woods, alongside some sparkling little 
lake and there while away the hours in peace and contentment, or join the multitudes who sit with rod and reel along the docks at St. Petersburg, or can sequester himself from the passing throngs by plunging into the forest primeval, taking his camp equipment and wandering days and weeks far from the habitation of man, far into the pathless jungles, under the pines and cypress, and can hunt and fish to his heart's content. He can find medicinal springs flowing like rivers from the bowels of the earth, their waters good for the healing of the nations, or sulphur streams forcing their way up from the ground through artesian conduits, or can while away the time amid groves redolent with the heavy perfume of the orange, and in nooks where the wild flower and bright plumaged bird are his only companions. He can go into the far away lumber camps, through the turpentine districts where the negroes have their humble shacks and where they live a free and easy life, or, join the multitudes as they throng the thoroughfares of busy cities. There is no lack of variety or interest. Tropical verdure, serene sunshine, blue skies, ocean breezes, sparkling lakes, dense jungles, wide stretches of prairie fringed with jagged trees, sandy beaches, rolling surges, they are all there and are for the enjoyment of the man who seeks them.

In thousands of instances the call comes, not entirely because of a desire for change, but there 
is added to it a pair of weak lungs, made so by exposure to the elements, a tendency to catarrh, ailing bronchial tubes, and the doctor says that the sudden transition from hot to cold and cold to hot in the northern states, shortens life, impairs health, weaken lungs, and breaks down strong constitutions, while the evener temperature of the farther south, the constant sunshine, the outdoor life, the invigorating breezes, bring back health and vigor, as well as give rest and recreation and change. How long will it take us to learn that an ounce of prevention is cheaper than a pound of cure, that a lung saved in the early stages of a sickness is worth something and a lung taken to some high altitude after it is too late is worthless? How infinitely better it would be to prevent sickness rather than to cure it. How long will it take us to learn that sunshine and outdoor life are the antidotes that nature has provided for declining health and weakened constitutions? Many hear the call of health and they strike out for the place where it may be found.

So it is that by the time January is well started the railroads have called into action all their available equipment for handling the swarming multitudes that are Florida bound. The little hotels in a hundred cities and by the side of a thousand lakes, and along the gulf, and the Atlantic, have brushed up the rooms, tidied up the parlor, renewed the cupboard, and made the porch look 
"homey." The alert host and the smiling hostess stand with outstretched hand to welcome the coming guest.

Where economy is a factor to be reckoned with subterfuges are naturally indulged. The whole winter's sojourn is accomplished with very little outlay by thousands. They choose their place, rent a room, do their own cooking in chafing dish fashion, and have earned the sobriquet of "tin can tourists." The name has just the least tinge of criticism in it and yet it is rarely deserved. Of course there are hard-fisted old tightwads who want to get through without spending anything, but in many cases the trip indulged in by the socalled tin-can tourist is one that has been ordered by the family doctor and it must be taken with great caution to the pocket book. These persons find that they can go to Florida and spend the winter with almost as little expense as they would incur by staying at home.

From January until April the hotels are surging with guests, the boarding houses are full, the bungalows, the cottages, the shacks, the outdoor cabins are all crowded to capacity. The sunshine floods in and sickness backs out. Life and health come through outdoor wandering. Fat old ladies sit on the front porch and tat or tattle as the case may be-usually both-but the others wander around, searching for enjoyment and finding health. 
Along the wharfs of a thousand little ports, up the quays, along the bayous, down the creeks, along the inlets, in boats and on the banks they are there in solid phalanx, with fishing poles and rods and reels and minnows, and worms, and fiddlers and sometimes with bottled bait, waiting for a bite. Occasionally somebody brings in a good one. The pelicans and gulls wheel around in the air above them. Then home, as the sun begins to set, for they cannot go in the dusk. There is no dusk or no gloaming in Florida. It is light and then it is dark, with no half-lighted intermission between. They fight off monotony and restlessness, and so, the winter goes, with its diversions, its excursions, its games, its revelings, its tramps, its sunshine baths, its lake and river and surf baths, its parties, its strolls in the moonlight, its incursions into the neighboring groves, its fish fries, its boating, its automobile drives, and its merry crowd around the little pine cone fire in the evening.

When the newspapers "up home" along in March and April, begin to talk about setting out garden, house-cleaning, and to give notice of the early approach of spring the majority fold their tents, and start on the home trail. Each year a large number who went down, are so pleased with the surroundings, so satisfied with health and living conditions, that they stay, and so the population statistics are being made up from that influx of sturdy citizens who have made successes in 
other states, in mine and mill and factory and store, and on the farm, and this kind transplants their homes, and the next we hear of them they are boosting for Florida, just as they have formerly boosted for Keokuk, Kalamazoo or Kansas City.

The call comes hauntingly to the sportsman, the angler, the disciple of old Isaac Walton, the man whose instincts run back to the time when all men made their livelihood by the chase or with the net. Some of us still have traces of that primal tendency towards the semi-barbaric, and education and culture do not remove them completely. It is not intimated that because a man is a confirmed hunter or angler that he is therefore part savage, but, just the same, it is the tendency of our forebears, coming down through the strains of blood through countless generations, that keeps the rod and the gun in such constant use. Your rod and reel angler can hardly explore a nook or cranny of the state where he is not within speaking distance of lakes filled with the smaller varieties of fish. If he is a game sportsman, looking for the fish that fights, such as the tarpon and the king fish, and possibly the shark, he can have sport to his heart's content, and he does not have to be particular in which direction he goes. This sport abounds around every key, along every shore, around every island, for this kind of fishing is to be had all along the twelve hundred miles of sea coast belonging to the state. 
The huntsman can lose himself in vast boundaries of timber, can wander through pine forests or amid cypress swamps, can penetrate the pathless jungles of the more remote sections, and will there find such game as will keep him busy. He does not need to be continually on the lookout for the irate farmer and the dread "posted" sign that is tacked so promiscuously all over the fields of other and older states. He can wander about for days and nights, careless of cold, sleeping in the open if he wishes, and can find plenty of game, little and big, depending upon the distance from known habitations that he cares to go. Many distinguished business barons and public men have their lodges and hunting quarters in Florida, to which they have for years gone for their annual hunt. To the sportsman Florida presents a field full of adventure and possibility, full of satisfaction such as comes to the man who has bagged his game.

Another class hears the call to Florida. Throughout the length and breadth of the nation and in many parts of the Dominion north there are throngs of people, who have hoarded consistently through many years; they have saved something for a rainy day. The children have perhaps married and gone off to homes of their own, or they may have died and left vacant chairs staring the old couple in the face, and the sunset is just over the hill. These couples have denied 
themselves luxuries and even comforts through many years because they were bracing themselves against the future when the period of production had passed. They have dreamed and talked throughout the long winter evenings of a little grove, a vine covered cottage, a little lake, some flowers, some chickens, a garden, a cow, health, contentment and plenty, some place in a dreamland where they could be free from the rigors and hardships of a long and bleak winter. They have dreamed a dream of Arcadia. It all seemed fantastic and unreal and impossible, but one day they learned that it was just as practicable as to live where they had been so many years, and that all the little touches that embellish a life of rest would be theirs at moderate cost. Increasing numbers of these people are settling on lake side and river, on coast and key, in various parts of Florida, intending to spend their declining days in quiet. They provide themselves with some satisfactory employment, the care of a small grove and garden, a flock of chickens, a cow, and are fixed to live an ideal existence.

Then there are many young and vigorous couples who look on this as a coming land, where the chances for advancement are much more rapid than in the older centers, so the vigor of youth is looking to Florida for a home and a place in which to carve out a fortune. There are large numbers of young men going there to take up a tract, in- 
vesting their muscle, their sweat, their thought. They build modestly, live economically, work hard. They keep holding on and to these there is the bag of gold at the end of the rainbow, for intelligent effort in Florida brings big dividends.

Florida calls to the farmer. How many a time, at eventide, after fourteen hours of strenuous work, the tiller of the soil on one of those little mountain farms, those hillside farms, in Tennessee or Kentucky or the Virginias, or along the foothills of the Alleghenies, after such work on the precipitous patch that he cultivates, has longed for a level piece of ground, where he might plow to his heart's content, without having one leg grow longer than the other, or where he could use a sulky plow or haul his crops into the barn in an ordinary road wagon. Energy put into the soil comes out in dividends. Energy expended in clambering up the sides of mountains and over cliffs to get a little patch of corn to growing is largely wasted. If a living can be extracted between the bluffs and on the side of the mountains, amid the rocks and crags and gullies, how much more reasonable to suppose that it can be brought forth from level, responsive soil, with the aid of a sun that matures the year round. Florida has a sunny smile for the iron muscled, earnest, intelligent, studious farmer. The indomitable and unconquerable spirit that will bring forth food for the family in the frowning fields of the mountain 
ranges will make a Florida farm bulge out with fatness.

Florida has a clarion call for the investor.

What new country does not?

Think of the fortunes that are pouring into the laps of those long-sighted men who, a few years ago, went into the mountainous districts of Tennessee and eastern Kentucky and West Virginia and bought up immense acreages of coal and timber territory for a song, ahead of the coming of the railroads. Lands that were bought at $\$ 1.00$ to $\$ 5.00$ an acre are rated today at $\$ 100$ to $\$ 1,000$ an acre. The fortunes came through foresight and buying ahead of development.

A well-to-do doctor from central Ohio spent some time in Florida and looked at real estate in different sections. The real estate men pointed out the supreme advantages of certain fast growing towns, but he was not interested. They lavished language on the importance of developed grove sections, but he did not fall for them. $\mathrm{He}$ finally explained that he had a grandson in whose future he was deeply interested and what he wanted was to buy something which would not develop soon, but which would make a patrimony for the growing boy. He was investing in futurities, and few can appreciate how wisely he had spoken. Florida has untold acres of "wild lands," far from the plow and fertilizer, laying in dense woods and as yet unthought of by the lot salesman 
or the colonist. As the circle of development widens it brings these lands a little nearer in with each revolving season. One of these days they will be in the center of things. Then look out. This was the case with Miami. In 1896, when Flagler's road reached that point it found a straggling town, a little store or two and a few score of people. Some gifted men bought substantial acreages at the time and pursued a watchful waiting policy. Those tracts are today in the center of the city and it would take mints of money to buy them.

In a smaller way the same thing is true of every square mile in the state. Where yesterday was a logging camp or a turpentine still, today is a small town, soon a thriving little city. Where the pine forest held undisputed sway last year, the young grove is planted today and tomorrow it will be an agricultural center. The ground that could have been acquired yesterday at $\$ 10$ or $\$ 25$ an acre is now quoted at $\$ 150$.

The fringe of the towns is an attractive place for the man with a little money. The center has reached its maximum, or is at least priced sufficiently high, but the outlying lands are generally very moderate, and the towns are enlarging their circumference rapidly. The garden of last week is the subdivision of this week. Someone starts building a home. Soon the garden is thickly settled with people and the original investment has 
been doubled, trebled, quadrupled. A concrete illustration. A party laid off a field just outside of one of Polk county's lesser cities two or three years ago. He offered it to some northern people at a price which averaged $\$ 15$ a lot. There were 300 lots. The writer saw the last of that bunch of lots sold and the price on the last one disposed of was $\$ 225$; quite a little advance for a property held only three years. Duplicates of this can be furnished in practically every city and town of the state. It is not plunging or real estate lottery or boosting or promoting or high financing. The increase simply comes from two facts. The prices on acreage have been comparatively low. The people have flowed into the state in such numbers that the demand for building sites was heavy. The profits have resulted naturally.

Every reading of the horoscope indicates that only the advance of the army of the hosts coming into the state for temporary or permanent homes has reached its destination and if this is true, there are few places on the globe which ought to offer better opportunities for investment in the next decade or two.

A man with a little money can do more with it in Florida than is possible in the older and more compactly built states because investments have not been pawed over and sorted out and laid aside and tried out. Things are novel and interesting and there is a spirit of taking hold of things. 
History may decline to repeat itself but handsome piles have been made out of the phosphate lands that persist in some ten counties. The same thing that happened to the wild coal lands of eastern Kentucky occurred in connection with these phosphate beds. The discovery of phosphate beds was something of an accident. Their discovery at present is the result of persistent search. At the beginning large boundaries of supposed phosphate lands were picked up at a merely nominal price. Many of these could not be bought now for $\$ 1,000$ an acre. There may be a million acres of phosphate beds yet that no one has stumbled on to. This is one of the imminent possibilities, while the long held theory that some day Florida would develop another oil field, like that at Beaumont, may be classed as one of the remoter improbabilities. You never can tell. 


\section{CHAPTER XXII. \\ "IT's UP TO YOU."}

WE have endeavored to set things down as they are, not to gloss over, or unduly praise. Florida is a part of the "old South." Heaven grant that it may never lose all the marks of the antebellum days. The old diamond stack locomotive is there, on some of the shorter branch railroads. The little log road with its wire rails is there. The lazy, shiftless nigger is there, so is the indifferent, languid looking, self-satisfied cracker. $\mathrm{He}$ is in the minority, it is true, but he is still there. The sleepy little town, with its coterie of loafers around the postoffice, is there. The big black buzzard sweeps watchfully over the tree tops and roofs, looking for dead ones, and sometimes finding one. It has all the air, the coloring, the characteristics of the extreme South. That is what makes it attractive to the average visitor. Remove these landmarks and one had as well be in Massachusetts on a hot day. We hope that Florida will never entirely lose its color as an old-time Southern state. Put the livest wire from the most up-to-the-minute section in the world down there and he imbibes some of this go-easy spirit after a time. He does not get indolent or lazy, but he comes down to the 
office a little later in the morning, and goes back home a little earlier in the evening, and finds more time to stop and pass the time of day with his acquaintances. He makes friends and learns that friendship is fed on pleasant talks at frequent intervals. He loses the restless, alert, impassioned way he had of making the dirt fly and adopts the serener course of taking his time so as not to wear out the machinery too soon. He gets along just as fast, makes as much money in the long run and has a great deal better time doing it.

This little book was written to put Florida in its real and actual light, so far as residence, acquaintance, travel, study and inquiry from a thousand sources could do it. It was not intended solely and primarily to tear a man loose from his moorings in the North or East or West, but to show him how things average up in a state which has uniformly been little understood by the mass of people.

It was not the purpose to fill it with figures and statistics, for there are enough of these already published to fill an encyclopedia. It has not been the object to hold out to the tourist or visitor or prospective tiller of the soil a land flowing with milk and honey. The milk is there, but you have to keep driving up the cow and milking her. The honey is there, but no apiaries are found wild. If some of the romantic literature of 
some of the promoting corporations have given rise to the dream that a man could live in Florida without money or work, it is just as well to wake up this side of Jacksonville. Every man and woman has to give consideration to the question of meal tickets. Whenever you see one who is not perturbed on this subject, set it down either that he has done serious work in his time and has gathered together a competence, or-that somebody is putting up the meal tickets for him. A man cannot live without work in Michigan or Colorado. Neither can he in Florida, although he can get along in the latter state with fewer clothes and a cheaper house, and the cost of living generally is lower in Florida than in many of the states.

Agriculturally, Florida has a soil that will produce things, as the statistics show, and a climate that is equable. Divested of all the fanciful things that have been said about miraculous production on small tracts, it will unquestionably yield handsomely where labor and fertilizer and brains go into the job.

It is a wholesome country in which to live. The people of Florida are not a whit behind the foremost sections of the Union in their advocacy of schools, churches, refinement, culture, social advancement, public improvements, good roads, loyalty to the nation and its traditions, civic righteousness, and they have a deep and abiding veneration for the home life. 
There is a picturesque enchantment about the Florida home. Those little embellishments in fixing up the grounds, those touches of refinement and distinction which are wrought out with laborious effort in more rigorous latitudes, and done sometimes in spite of Nature's protest, come naturally and unbidden in Florida, because the wealth of tropic verdure lends an air of fairyland to every scene. You have waked up some frosty morning and found the whole of nature draped in white and gleaming trappings wrought out during the night by the frost. The boughs of the trees, the dry leaves, the grass, the wires, the house tops were all covered with a filmy drapery of white and around all was a heavy fog which made all the earth seem unreal and fantastic. You get the same effect in Florida when you see the tall pine, or the gnarled cypress or the wide spreading water oak hanging heavy with festoons of that weird pirate, the Spanish moss. Add to this the charm of fifty varieties of the palm family, the gaudy poinciana, the graceful eucalyptus, the breath of the orange trees, the enchantment of mirror-like lakes, and even the most unromantic can see that nature has furnished in this half tropic land all the essentials for ideal dwelling places.

And, surely, not even the dullest materialist but that will admit that, as a country, we need a tonic. We have been traveling too fast. The nation needs more rest and relaxation and recuperation 
and less patent medicines and massage parlors and sanitariums. It should take this rest during the rigorous months of winter. It needs sun baths and serene interviews with mother nature rather than society stunts, parades on the Board Walk, and the gay frivolities of fashionable watering places-places where water is ofttimes unknown. We go at a killing pace, tear down the tissues. We unravel the nerve centers. We expose our throats and impair our lungs. We dress foolishly and face sleet and rain and snow and blizzard and fog and ice, until nature quits trying and we seek the doctor.

Florida is a tonic for the sick. It is no magic healing spring. It has no distinct fountain of youth. It simply has a monopoly from November till April on the world's supply of sunshine and blue skies and warm breezes. For that reason a million hard-worked, excitable, nervous Americans would make the best investment of their lives if, when the first chill blasts begin to blow from out the North country, they would close down their desks, bid good-bye to their business perplexities and transplant themselves for three or four months to the land of the lakes. They would come back to their duties in early spring renewed and invigorated.

The man who has made and saved his money, and who has cherished a dream all through the years of a quiet spot in which to spend his sun- 
set days, is going to Florida. A wonderful company of these are already there. Here is the first impression of one of them and the way many of them feel and how they write back home:

"Well, wife, I've found the promised land, I hove in here today,

Slid from an iceberg, through the snow Kerplunk into middle of May.

I've always hesitated some,

A handin' out my hand

To any of those blamed erack shots

Of Lee and Jackson's band.

Thought they wuz slow, and lazy like, An' offish, an' some proud:

Fact is, in '63 they wus

A darn pestiferous erowd.

But, pshaw, the welcome that I got Wuz so spontayous that

It knocked my ol' time prejudis Into a small cocked hat.

The land's jes like a picture book Held up before your eyes, You'd think the trainman set you off Right smack in Paradise.

There's great big palms a settin' round, They must come scand'lous low, An' flowers, an' orange trees, an' things That makes a scrumptious show. 
The homes are not big palaces, Like castles on the Rhine, But, By Heck, they've got comfort writ All over every line.

I saw big fields of garden sass, All green, row after row, And couldn't realize that you Are back home, shovelin' snow.

An' when the stars peeped out last night, An' the soothin' south wind blew, All that it lacked of the Garden of Eden Was that I didn't have you.

Now wife I'll tell you what I've done, I jes made up my mind That this land's good enough for us, The purtiest spot we'll find.

I bought a little place today

The others all bought, too, An' give my orders for a house, Jes right for me and you.

So, pack the things, an' come on down, Fer Goodness sake, be spry,

I'm thawed out now, and feelin' fine, Up there I'd freeze and die.

You know our race will soon be run, We've faced the storms together, The balance of our trip we'll have Fair skies an' summer weather." 






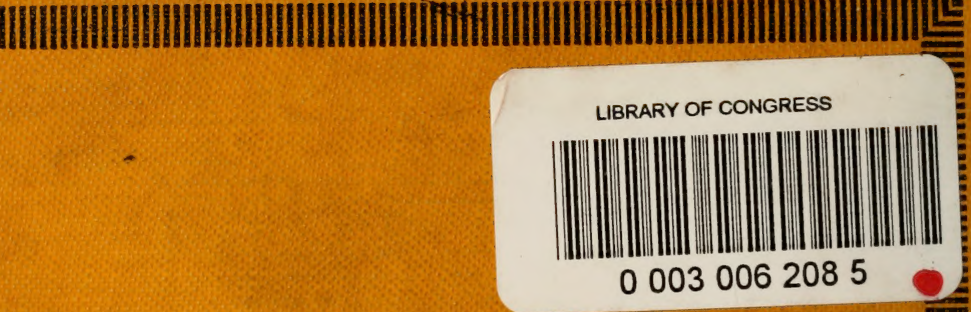

DERHAPS no part of the habitable Globe has been as indiscreetly praised and as blatantly maligned as Florida - The Author has spent many years investigating the conditions in Florida, and here SETS FORTH THE FACTS so that the man who contemplates the purchase of land, or who is considering a winter home, or who seeks investment or who merely is looking for information may have an uncolored view of the State from an authoritative and unbiased source. 